\title{
New fossils of Hyaenodonta (Mammalia) from the Eocene localities of Chambi (Tunisia) and Bir el Ater (Algeria), and the evolution of the earliest African hyaenodonts
}

\author{
Floréal Solé, El Mabrouk Essid, Wissem Marzougui, Rim Temani, \\ Hayet Khayati Ammar, Mhammed Mahboubi, Laurent Marivaux, \\ Monique Vianey-Liaud, and Rodolphe Tabuce
}

\begin{abstract}
We present and describe new fossils from the Eocene North African localities of Chambi (Tunisia; late Ypresian or early Lutetian) and Bir el Ater (Algeria; latest Bartonian or earliest Priabonian). The specimens from Chambi allow recognizing two recently described hyainailourines: Furodon crocheti and Parvavorodon gheerbranti; these taxa were previously known from the Gour Lazib area (Algeria; late Ypresian or early Lutetian). The new material from Tunisia includes a fragmentary dentary of Parvavorodon that substantially supports the hyainailourine status of this genus and represents the oldest dentary fragment presently known for a juvenile of Hyaenodonta in Africa. The presence of Furodon and Parvavorodon in Chambi strengthens support for the hypothesis of contemporaneity of the Eocene Gour Lazib and Chambi mammalbearing localities. In addition, the find of a typical teratodontine fourth premolar in Chambi testifies to the presence of a small representative of this group. The fossil record in Bir el Ater is scarcer than in Chambi. However, we recognize specimens attributable to a hyainailourine and a teratodontine. The latter is referred as Masrasector cf. ligabuei, and is the oldest record for this genus. We tentatively identify a modification of the hyaenodont fauna in the Maghreb after the "Early Eocene Climatic Optimum" (EECO). This faunal change might be related to the decrease of the global temperature after the EECO event. It appears contemporaneous of a drastic replacement in the composition of the mammal faunas in Africa. Finally, the end of the Eocene (Priabonian) shows an increase in the subfamilial richness amongst hyaenodonts.
\end{abstract}

Floréal Solé. D.O. Earth and history of Life, Department of Paleontology, Royal Belgian Institute of Natural Sciences, Rue Vautier 29, B-1000 Brussels, Belgium. fsole@naturalsciences.be

El Mabrouk Essid. Office National des Mines (ONM), 24 rue 8601, 2035 La Charguia, Tunis BP: 215 1080 Tunis, Tunisia.mab_04@yahoo.fr

Wissem Marzougui. Office National des Mines (ONM), 24 rue 8601, 2035 La Charguia, Tunis BP: 215 1080 Tunis, Tunisia.wi_marzougui@yahoo.fr

Rim Temani. Office National des Mines (ONM), 24 rue 8601, 2035 La Charguia, Tunis BP: 215 - 1080 Tunis, Tunisia. rim.temani@onm.nat.tn Hayet Khayati Ammar. Office National des Mines (ONM), 24 rue 8601, 2035 La Charguia, Tunis BP: 215 1080 Tunis, Tunisia. khayatihayet@yahoo.fr

Solé, Floréal, Essid, El Mabrouk, Marzougui, Wissem, Temani, Rim, Ammar, Hayet Khayati, Mahboubi, Mhammed, Marivaux, Laurent, Vianey-Liaud, Monique, and Tabuce, Rodolphe. 2016. New fossils of Hyaenodonta (Mammalia) from the Eocene localities of Chambi (Tunisia) and Bir el Ater (Algeria), and the evolution of the earliest African hyaenodonts. Palaeontologia Electronica 19.3.41A: 1-23 palaeo-electronica.org/content/2016/1598-new-eocene-african-hyaenodonts 
Mhammed Mahboubi. Laboratoire de Paléontologie stratigraphique et Paléoenvironnement, Université d'Oran, B.P. 1524 El M'naouer, Oran 31000, Algeria. mahboubi.med@gmail.com Laurent Marivaux. Laboratoire de Paléontologie, Institut des Sciences de l'Évolution de Montpellier (ISEM, UMR 5554, UM, CNRS, IRD, EPHE), c.c. 064, Université de Montpellier, Place Eugène Bataillon, F34095 Montpellier Cedex 05, France. laurent.marivaux@umontpellier.fr Monique Vianey-Liaud. Laboratoire de Paléontologie, Institut des Sciences de l'Évolution de Montpellier (ISE-M, UMR 5554, UM, CNRS, IRD, EPHE), c.c. 064, Université de Montpellier, Place Eugène Bataillon, F-34095 Montpellier Cedex 05, France. monique.vianey-liaud@umontpellier.fr

Rodolphe Tabuce. Laboratoire de Paléontologie, Institut des Sciences de l'Évolution de Montpellier (ISEM, UMR 5554, UM, CNRS, IRD, EPHE), c.c. 064, Université de Montpellier, Place Eugène Bataillon, F34095 Montpellier Cedex 05, France. rodolphe.tabuce@umontpellier.fr

Keywords: Teratodontinae; Hyainailourinae; Koholiinae; Apterodontinae; North Africa; Paleogene

Submission: 16 September 2015 Acceptance: 18 August 2016

\section{INTRODUCTION}

The hyaenodonts are extinct placental carnivorous mammals that were successful during the Paleogene in Africa (e.g., Savage, 1965; Holroyd, 1994) and Laurasia, especially in Europe and North America (e.g., Gingerich and Deutsch, 1989; Tong and Wang, 2006; Solé et al., 2014a). For a long time, they have been grouped with the Oxyaenidae within the "Creodonta", an order of extinct placental carnivorous mammals, but "Creodonta" is probably diphyletic (Polly, 1996; Solé, 2013; Zack, 2013). There are three competing hypotheses regarding the geographic origins of the Hyaenodonta: (1) Gheerbrant (Gheerbrant, 1995; Gheerbrant et al., 2006) and Solé (Solé, 2013; Solé et al., 2009, 2014b, 2015), following Gingerich and Deutsch (1989) have proposed an African origin based on a very early record for the family in Morocco (Gheerbrant, 1995; Solé et al., 2009) their presence can now be extended back to the middle Paleocene (i.e., Selandian; Yans et al., 2014); (2) an Asian origin has been advocated by several authors (Beard, 1998; Meng et al., 1998), primarily on the basis of the Paleocene occurrence of the Limnocyoninae from Inner Mongolia, China; (3) Morlo et al. (2009) has proposed a multiregional origin, which implies that two distinct groups of Hyaenodonta originated in different landmasses: the Proviverroidea (Proviverrinae and Tinerhodon) in Africa, and the Hyaenodontida (Sinopinae, Limnocyoninae) in Asia.

While the Laurasian hyaenodonts faced numerous competitors (Oxyaenodonta, Carnivoramorpha; Morlo et al., 2010), the African ones evolved without competitors in isolated conditions until the closure of the Tethys at the Oligocene/Miocene transition (ca. $\sim 23$ m.y.). This likely favoured the diversification of the African hyaenodonts, a hypothesis which is well exemplified by the Priabonian-Rupelian faunas from the Fayum Depression in Egypt (e.g., Andrews, 1906; Osborn, 1909; Simons and Gingerich, 1974, 1976; Holroyd, 1994, 1999). However, their pattern of diversification has remained poorly understood in deeper times due to the scarce Paleocene-Eocene African fossil record.

In order to further our understanding of the Eocene radiation of hyaenodonts in Africa, we review the available paleontological evidence and present new fossils from two Eocene localities: Chambi (Tunisia; late Ypresian or early Lutetian) and Bir el Ater (Algeria; latest Bartonian or earliest Priabonian).

In Afro-Arabia, 10 regions have so far yielded hyaenodonts in Paleocene and early Oligocene (= Rupelian) deposits: nine sites are located in North Africa and Arabia (Ouled Abdoun Basin [Morocco]; Ouarzazate Basin [Morocco]; El Kohol [Algeria]; Gour Lazib [Algeria]; Chambi [Tunisia]; Bir el Ater [Algeria]; Dur at-Talah [Libya]; Taqah [Oman]; Fayum Depression = Birket Qarun Formation $(\mathrm{BQ}-$ 2), Qasr el-Sagha Formation (e.g., L-25, L-66, and L-45) , and Jebel Qatrani Formation (e.g., Quarry I, Quarry M, and L-41), and Qasr el-Sagha Formation (e.g., L-25, L-66, and L-45) [Egypt]); and only one in the Southern part of the continent (Black Crow locality from Sperrgebiet [Namibia]) (Figure 1.1). These localities range from the middle Paleocene (Selandian) up to the Rupelian (Figure 1.2). The taxa for each locality are listed in Table 1.

In addition to the Paleocene Tinerhodon (Hyaenodonta incertae sedis), African hyaenodonts document four subfamilies: Koholiinae, Teratodontinae, Hyainailourinae, and Apterodontinae 


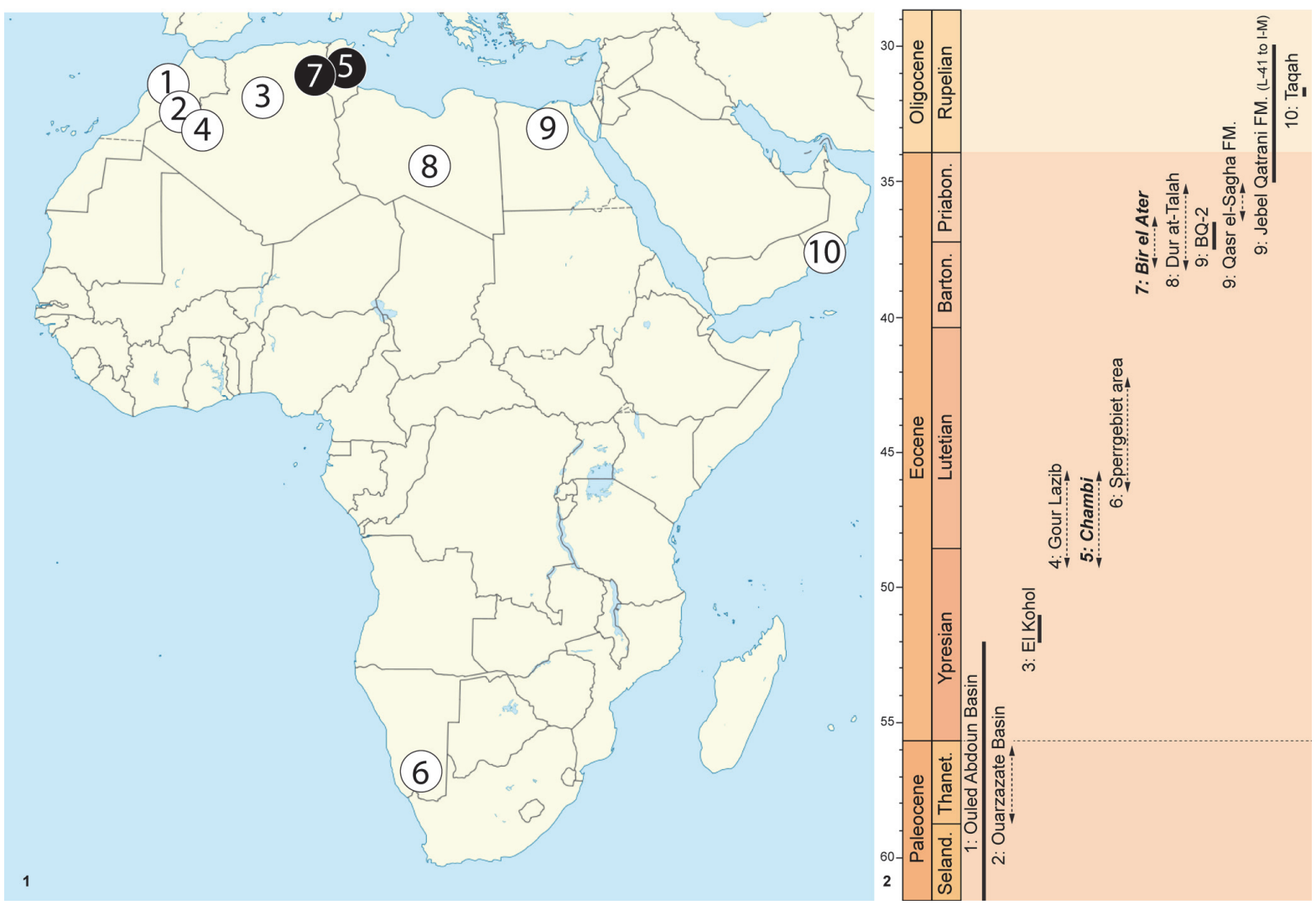

FIGURE 1. 1, localisation of the African fossiliferous localities that yielded Paleocene and Eocene hyaenodonts (see Table 1); 1: Ouled Abdoun Basin (Morocco); 2: Ouarzazate Basin (Morocco); 3: El Kohol (Algeria); 4: Gour Lazib (Algeria); 5: Chambi (Tunisia); 6: Black Crow locality from Sperrgebiet (Namibia); 7: Bir el Ater (Algeria); 8: Dur atTalah (Libya); 9: Fayum Province = Birket Qarun Locality 2, Jebel Qatrani, and Qasr el-Sagha Formation (Egypt); 10: Taqah (Oman). 2, correlation of Eocene localities including hyaenodonts (see Table 1) [adapted from Coster et al. (2012, figure 1) and Seiffert (2010, figure 2.1)]. The black circles (1) and the names in Bold Italic (2) identify the localities under study. Abbreviations: Barton.= Bartonian; Priabon.= Priabonian; Seland.= Selandian; Thanet.= Thanetian.

(Table 1) (Solé, 2013; Solé et al., 2014b). These subfamilies mainly radiated in Africa (Savage, 1965; Lange-Badré, 1979; Holroyd, 1994, 1999; Solé et al., 2009; Grohé et al., 2012). The fossils recently described from the Gour Lazib (Algeria) appeared critical for a better knowledge of the hyaenodont evolution in Africa, because they represent the oldest taxa recorded for two of the four subfamilies: the Hyainailourinae and Teratodontinae (Solé et al., 2014b).

The Tunisian locality of Chambi (Figure 1.1), dating from the late Ypresian or early Lutetian (Figure 1.2), has yielded mammal fossils since the mid 1980s (e.g., Hartenberger et al., 1985, 1997, 2001). These fossils have strongly contributed to clarify the early evolution of some mammal groups in Africa, notably the elephant-shrews (Hartenberger, 1986; Tabuce et al., 2007; Benoit et al., 2013a), primates (Hartenberger and Marandat, 1992; Marivaux et al., 2013), rodents (Vianey-
Liaud et al., 1994; Marivaux et al., 2015), bats (Ravel et al., 2011a, 2012, 2015, in press), hyracoids (Court and Hartenberger, 1992; Tabuce et al., 2011), and sirenians (Benoit et al., 2013b). The presence of carnivorous mammals in the Tunisian locality had, however, never been reported thus far.

The fossil locality of Bir el Ater, which is located in the Nementcha Mountains (North-eastern Algeria) (Figure 1.1), is much younger than Chambi: its age is generally considered to be either latest Bartonian or earliest Priabonian (Figure 1.2). It has yielded a diverse assemblage of mammals including rodents (Coiffait et al., 1984; Jaeger et al., 1985; Marivaux et al., 2014a), primates (de Bonis et al., 1988; Tabuce, 2002), an elephantshrew (Tabuce et al., 2001a), a hyracoid (Tabuce et al. 2000), and a proboscidean (Delmer et al., 2006). Tabuce et al. (2001b) listed the presence of creodonts gen. and sp. indet. in the faunal list of Bir el Ater, a materiel that we describe here. 


\section{Solé et Al.: New EOCEnE African hyAenOdonts}

TABLE 1. Distribution of the hyaenodonts presently known in the Paleocene and Eocene of Africa. Ouled Abdoun Basin: Gheerbrant et al. (2006) and Solé et al. (2009); Ouarzazate Basin: Gheerbrant (1995; et al., 2006); El Kohol: Crochet (1988); Gour Lazib area: Solé et al. (2014b); Black Crow locality from Sperrgebiet: Pickford et al. (2008); Dur at-Talah: Grohé et al. (2012); Birket Qarun Locality 2: Borths et al. (2010); Jebel Qatrani and Qasr el-Sagha Formations: Simons and Gingerich (1974, 1976), Holroyd (1994, 1999), Lewis and Morlo (2010); Taqah: Crochet et al. (1990); Chambi and Bir el Ater based on the present paper. *: Taxa described in Holroyd (1994) but not formally published. First column refers to Figure 1 localities/

\begin{tabular}{|c|c|c|c|c|c|c|c|}
\hline & $\begin{array}{c}\text { Faunal } \\
\text { Assemblage }\end{array}$ & Localities & $\begin{array}{c}\text { Incertae } \\
\text { sedis }\end{array}$ & Teratodontinae & Koholiinae & Hyainailourinae & Apterodontinae \\
\hline 10 & III & Taqah & - & Masrasector ligabuei & - & - & - \\
\hline \multirow[t]{7}{*}{9} & III & $\begin{array}{c}\text { I and } \mathrm{M} \\
\text { (Jebel Qatrani } \\
\text { Formation) }\end{array}$ & - & $\begin{array}{l}\text { Masrasector } \\
\text { pithecodacos* }\end{array}$ & - & $\begin{array}{l}\text { Pterodon syrtos } \\
\text { Pterodontine A }\end{array}$ & $\begin{array}{c}\text { Apterodon } \\
\text { macrognathus }\end{array}$ \\
\hline & III & $\begin{array}{c}\text { G and V } \\
\text { (Jebel Qatrani } \\
\text { Formation) }\end{array}$ & - & $\begin{array}{c}\text { Masrasector } \\
\text { aegypticum } \\
\text { Metasinopa osborni }\end{array}$ & $\begin{array}{l}\text { Metapterodon } \\
\text { schlosseri }\end{array}$ & Pterodontine C & - \\
\hline & III & $\begin{array}{c}\mathrm{E} \\
\text { (Jebel Qatrani } \\
\text { Formation) }\end{array}$ & - & Masrasector ligabuei & - & Pterodon sp. & $\begin{array}{l}\text { Apterodon } \\
\text { macrognathus } \\
\text { Apterodon } \\
\text { altidens }\end{array}$ \\
\hline & III & $\begin{array}{c}\text { A and B } \\
\text { (Jebel Qatrani } \\
\text { Formation) }\end{array}$ & & $\begin{array}{c}\text { Brychotherium } \\
\text { ephalmos* } \\
\text { Masrasector ligabuei }\end{array}$ & $\begin{array}{l}\text { Metapterodon } \\
\text { schlosseri }\end{array}$ & \begin{tabular}{|} 
Pterodon africanus \\
Pterodon \\
phiomensis \\
Akhnatenavus \\
leptognathus
\end{tabular} & $\begin{array}{l}\text { Apterodon } \\
\text { macrognathus } \\
\text { Apterodon } \\
\text { altidens }\end{array}$ \\
\hline & III & $\begin{array}{c}\text { L-41 } \\
\text { (Jebel Qatrani } \\
\text { Formation) }\end{array}$ & - & $\begin{array}{c}\text { Brychotherium } \\
\text { ephalmos } \\
\text { Masrasector ligabuei }\end{array}$ & - & $\begin{array}{c}\text { Akhnatenavus aff. } \\
\text { leptognathus } \\
\text { Pterodontine D }\end{array}$ & - \\
\hline & III & $\begin{array}{c}\text { Qasr el-Sagha } \\
\text { Formation }\end{array}$ & - & - & $\begin{array}{l}\text { Metapterodon } \\
\text { sp. }\end{array}$ & - & $\begin{array}{c}\text { Apterodon } \\
\text { saghensis } \\
\text { Apterodon sp. }\end{array}$ \\
\hline & III & $\begin{array}{l}\text { Birket Qarun } \\
\text { Locality } 2\end{array}$ & - & ?Masrasector & - & - & - \\
\hline 8 & III & Dur at-Talah & - & - & - & - & $\begin{array}{c}\text { Apterodon } \\
\text { langebadreae } \\
\text { Apterodon indet. }\end{array}$ \\
\hline 7 & II & Bir el Ater & - & $\begin{array}{c}\text { Masrasector cf. } \\
\text { ligabuei }\end{array}$ & - & $\begin{array}{l}\text { Hyainailourinae } \\
\text { indet. }\end{array}$ & - \\
\hline 6 & II & $\begin{array}{l}\text { Sperrgebiet } \\
\text { area }\end{array}$ & - & Teratodontinae indet. & - & Pterodon sp. & - \\
\hline 5 & II & Chambi & - & Teratodontinae indet. & - & $\begin{array}{c}\text { Furodon crocheti } \\
\text { Parvavorodon } \\
\text { gheerbranti }\end{array}$ & - \\
\hline 4 & II & $\begin{array}{l}\text { Gour Lazib } \\
\text { area }\end{array}$ & - & $\begin{array}{c}\text { Glibzegdouia } \\
\text { tabelbalaensis }\end{array}$ & - & $\begin{array}{c}\text { Furodon crocheti } \\
\text { Parvavorodon } \\
\text { gheerbranti }\end{array}$ & - \\
\hline 3 & 1 & El Kohol & - & - & Koholia & - & - \\
\hline 2 & 0 & $\begin{array}{c}\text { Ouarzazate } \\
\text { Basin }\end{array}$ & $\begin{array}{c}\text { Tinerhodon } \\
\text { disputatus } \\
\text { ?Proviverrinae }\end{array}$ & - & - & - & - \\
\hline \multirow[t]{2}{*}{1} & \multirow[t]{2}{*}{ I } & \multirow[t]{2}{*}{$\begin{array}{l}\text { Ouled Abdoun } \\
\text { Basin }\end{array}$} & \multirow[t]{2}{*}{-} & \multirow[t]{2}{*}{-} & $\begin{array}{c}\text { Ypresian: } \\
\text { Boualitomus }\end{array}$ & \multirow[t]{2}{*}{-} & \multirow[t]{2}{*}{-} \\
\hline & & & & & $\begin{array}{l}\text { Selandian: } \\
\text { Lahimia }\end{array}$ & & \\
\hline
\end{tabular}




\section{MATERIAL AND METHODS}

In the following text, fossils referenced CBI-1$x x$ and $U O N-x x$ are housed in the paleontological collections of the Office National des Mines of Tunis, Tunisia and the Université de Montpellier, France, respectively.

Institutional abbreviations. BC, Black Crow (Namibia); CBI, Chambi (Tunisia); HGL, Hammada Gour Lazib (Algeria); UON, Université d'Oran Nementcha, Bir el Ater (Algeria); NHMUK; Natural History Museum (United Kingdom); NMHW, Fossil Vertebrate Collection, Naturhistorisches Museum Wien (Austria).

The terminology of the molar cusps and crests follows Van Valen (1966). The measurements (length $\times$ width in $\mathrm{mm}$ ) follow Gingerich and Deutsch (1989).

Abbreviations. $D D=$ Dentary Depth; $L=$ Length; $n$ = number of specimens; OR = Observed Range; $\mathrm{W}$ $=$ Width.

\section{SYSTEMATIC PALAEONTOLOGY}

Class MAMMALIA Linnaeus, 1758

Grand order FERAE Linnaeus, 1758

Order HYAENODONTA Van Valen, 1967

Family HYAENODONTIDAE Leidy, 1869

Subfamily HYAINAILOURINAE Pilgrim, 1932

FURODON Solé, Lhuillier, Adaci, Bensalah,

Mahboubi, and Tabuce, 2014b

Type Species. Furodon crocheti Solé, Lhuillier, Adaci, Bensalah, Mahboubi, and Tabuce, 2014b

Furodon crocheti Solé, Lhuillier, Adaci, Bensalah, Mahboubi, and Tabuce, 2014b

Figure 2, Table 2

Referred specimens. $\mathrm{CBI}-1-550$, right $\mathrm{P} 2$; $\mathrm{CBI}-1$ 551 , right maxillary fragment bearing $\mathrm{P} 2$; $\mathrm{CBI}-1-$ 552, right $\mathrm{M} 1$; $\mathrm{CBI}-1-612$, right dp3; $\mathrm{CBI}-1-553$, fragment of left $\mathrm{m} 1$ (trigonid); $\mathrm{CBI}-1-554$, fragment of right $\mathrm{m} 3$ (trigonid).

Measurements. Table 2.

Description. Two P2s were found in $\mathrm{CBI}-1$ (Figure 2.1-4). The teeth are simple: the parastyle and protocone are absent, while the postmetacrista was probably poorly developed (low and short). The teeth are asymmetric in lateral view, the distal crest of the paracone being longer and more oblique than the mesial one.

The M1 is characterized by the reduction of the parastyle and paracone, and the elongation of the postmetacrista (Figure 2.5-6). The short parastyle allows referring the tooth as a M1. The apices of the paracone and metacone are not fused; the two cusps were probably similar in height. The paraconule and metaconule are present despite the reduction in length of the protofossa. The stylar shelf is reduced. There is no trace of lingual cingulum.

$\mathrm{CBI}-1-612$ (Figure 2.7-9) is mesiodistally elongated. The paraconid is clearly individualized; at its base, the lingual cingulid forms a bulge. The talonid is very short and displays two tiny cusps (protostylid and hypoconulid) (Figure 2.8). A strong cingulum is present along the lingual part of the talonid.

The trigonid $\mathrm{CBI}-1-554$ is characterized by the mesial position of the paraconid and the elongation of the paracristid (Figure 2.10-12). The metaconid is clearly smaller and narrower than the paraconid and protoconid. The precingulid along the labial side of the paraconid is large. The second fragment of the lower molar (CBI-1-553) is smaller than $\mathrm{CBI}-1-553$ (Figure 2.13-15), and its paracristid is less mesiodistally oriented.

Discussion. Concerning the loci of the fragmentary molars, we think that the trigonid $\mathrm{CBI}-1-554$ is a part of a $\mathrm{m} 3$, due to the mesial position of the paraconid and elongation of the paracristid, and that the trigonid $\mathrm{CBI}-1-553$ corresponds to that of a $\mathrm{m} 1$ because of its small size and its less mesiodistally oriented paracristid.

The fossils from Chambi CBI- 1 described above display secant morphology, especially the molars. The elongation of the paracristid and postmetacrista on lower and upper molars, respectively, and the reduction of the metaconid on $\mathrm{m} 3$ remind the distinctive features of Furodon crocheti. This hyainailourine has been recently described based on a dentary and upper molars from the Gour Lazib (Algeria). Furthermore, the size of the fossils from $\mathrm{CBI}-1$ matches that of the specimens from the Gour Lazib. In this context, we confidently attribute this new material from Chambi to Furodon crocheti.

The case of the two P2s and of the dp3 is less clear because these loci were unknown for Furodon crocheti. The morphology of the two upper teeth is compatible with that of the P2 known in hyainailourines, and their sizes agree with the measurements made on the base of the roots of the p2 present on the holotype of Furodon crocheti. The morphology of CBI-1-612 (e.g., large paraconid and presence of a lingual cingulum) reminds that of several dp3s known for Hyaenodon (Bastl et al., 2011, 2014). Moreover, the size of the tooth agrees with that of the premolars of Furodon cro- 


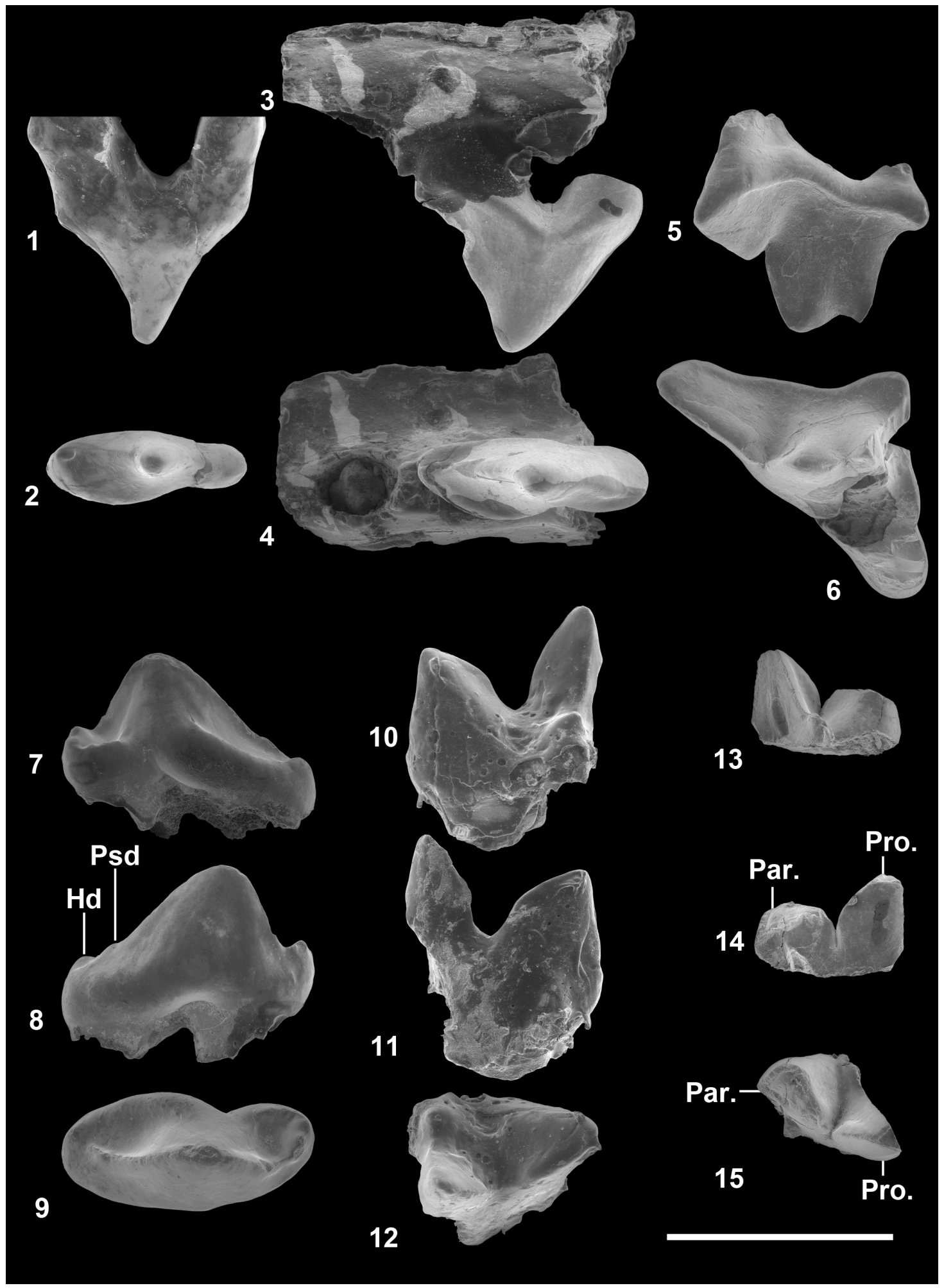

FIGURE 2. Furodon crocheti Solé et al., 2014b from Chambi CBI-1 (Tunisia). 1-2, CBI-1-550, right P2 in lingual (1) and occlusal (2) views. 3-4, CBI-1-551, right maxillary fragment bearing a P2 in labial (3) and occlusal (4) views. 5-6, $\mathrm{CBI}-1-552$, right $\mathrm{M} 1$ in labial (5) and occlusal (6) views. 7-9, CBI-1-612, right dp3 in lingual (7), labial (8) and occlusal (9) views. 10-12, CBI-1-554, left $\mathrm{m} 3$ in lingual (10), labial (11) and occlusal (12) views. 13-15, CBI-1-553, right m1 in lingual (13), labial (14) and occlusal (15) views. Abbreviations: Hd, Hypoconulid; Par., Paraconid; Pro., Protoconid; Psd, Protostylid. Scale bar equals $5 \mathrm{~mm}$. 
TABLE 2. Measurements (in $\mathrm{mm}$ ) of the specimens of Furodon crocheti Solé et al., 2014b from Chambi. *: fragmentary specimen.

\begin{tabular}{cccc}
\hline Locus & & $\mathbf{n}$ & OR \\
\hline P2 & L & 2 & $4.5-4.82$ \\
& W & 2 & $1.64-1.8$ \\
M1 & L & 1 & 5.74 \\
& W & 1 & 5.22 \\
\hline dp3 & L & 1 & 5.84 \\
& W & 1 & 2.56 \\
m1 & L & 1 & $2.86^{*}$ (trigonid) \\
& W & 1 & $2.32^{*}$ \\
m3 & L & 1 & $4.34^{*}$ (trigonid) \\
& W & 1 & $2.98^{*}$ \\
\hline
\end{tabular}

cheti. Consequently, we consider that CBI-1-612 represents a dp3 of this species.

The reference to Furodon crocheti of $\mathrm{CBI}-1$ 550, CBI-1-551, and CBI-1-612 seems to be the most appropriate taxonomic option.

Age and locality. Late Ypresian or early Lutetian; Chambi CBI-1 (Tunisia).

PARVAVORODON Solé, Lhuillier, Adaci, Bensalah, Mahboubi, and Tabuce, 2014b

Type species. Parvavorodon gheerbranti Solé, Lhuillier, Adaci, Bensalah, Mahboubi, and Tabuce, 2014b

Parvavorodon gheerbranti Solé, Lhuillier, Adaci, Bensalah, Mahboubi, and Tabuce, 2014b Figures 3-5, Table 3

Referred specimen. CBI-1-555, left P3; CBI-1556, left M1or2; $\mathrm{CBI}-1-557$, left p2; $\mathrm{CBI}-1-558$, right $\mathrm{m} 1$; CBI-1-559, left m3; CBI-1-613, left dentary bearing dp4, $\mathrm{m} 1$, alveoli of $\mathrm{dp} 3$ and $\mathrm{m} 2$, and distal alveolus of dp2?.

Measurements. Table 3.

Description. The P3 exhibits a simple morphology (Figure 3.1-2): the only known specimen is worn, which prevents from identifying the parastyle, but this latter was certainly weak. The metastyle is large but low. We identify the tooth as a P3 due to the enlargement of its base in the lingual side. This corresponds to the usual position of the protocone on P3 and P4; the latter is, however, more individualized and slightly more mesially located on P4 than on P3.

On the unique upper molar discovered (Figure 3.3-4), the paracone is less developed than the metacone and appears mesiodistally narrower. The parastyle is broken but it was certainly large based on the surface of breakage - the tooth thus could represent a M2. Despite its breakage, the postmetacrista is elongated. The protofossa is short and narrow despite the presence of the paraconule and metaconule. The stylar shelf is strongly reduced. No cingulum is visible.

The dentary is narrow - its depth only slightly exceeds the length of the $\mathrm{m} 1$ (Table 2). A mental foramen is present below the dp3 (see below for the determination of this locus); it corresponds to the most distal one of the two mental foramina, which are generally observed in Hyaenodonta. There is no diastema between dp2, dp3, and dp4.

The most mesial tooth preserved (dp4) on the dentary is characterized by a very low trigonid that is elongated mesiodistally. This feature is characteristic of the dp4 in Hyaenodonta. Indeed, the paraconid occupies a mesial position. It is slightly lower than the metaconid and protoconid. The protoconid is roughly at the same elevation than the paraconid. The metaconid is clearly more distally located than the protoconid. The talonid is - as the trigonid - elongated mesiodistally. The postfossid is narrow. The hypoconid, hypoconulid, and entoconid are distinguishable in occlusal view (Figure 4.3-4). The entoconid appears less individualized than the two other talonid cusps. A strong precingulid is visible.

On the fragmentary dentary (Figure 4), the presence of two foramina can be observed in occlusal view (black arrows on Figure 4.2). The most distal foramen is located between the roots of $\mathrm{dp} 4$; the second foramen is visible between the two alveoli that are mesial to the dp4. These foramina seem to be related to the eruption of the permanent teeth. This has been indeed observed in Hyaenodon (K.A. Bastl, personal commun., 2015). The presence of a foramen suggests that the two alveoli located mesially to the dp4 correspond to that of a dp3.

We made CT-scan reconstructions of $\mathrm{CBI}-1$ 613 in order to determine whether germs were present or not. No germ is visible neither below dp4 nor below dp3 (Fig. 5). As shown by Bastl et al. (2011) and Bastl et al. (2014), there isn't necessarily a germ visible for $\mathrm{p} 3$ and $\mathrm{p} 4$, when a fully erupted $\mathrm{m} 2$ is present. This absence of germs below these deciduous teeth (while $\mathrm{m} 2$ is present) was actually similarly observed for the mandible NMHW2009z0082/0002 referred as Hyaenodon sp. (Bastl et al., 2011, figure 1): the mandible shows p1, dp4, m1, and the alveoli of dc, dp2, dp3, and $\mathrm{m} 2$, while the X-ray only reveals the germs of p2 and the canine. Based on this data (i.e., absence of germ and presence of a foramen in 


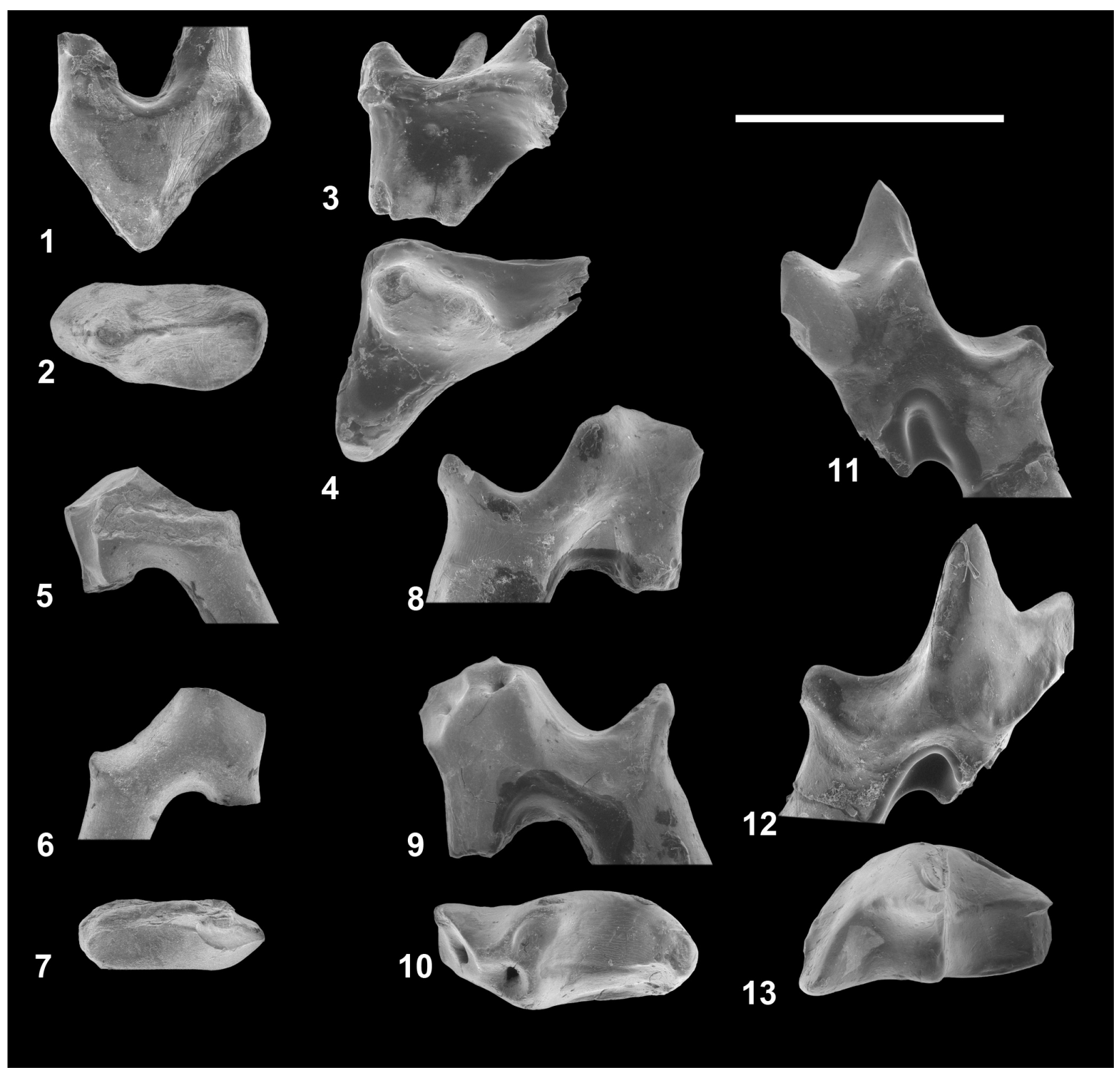

FIGURE 3. Parvavorodon gheerbranti Solé et al., 2014b from Chambi CBI-1 (Tunisia). 1-2, CBI-1-555, left P3 in labial (1) and occlusal (2) views. 3-4, CBI-1-556, left M1 or2 in labial (3) and occlusal (4) views. 5-7, CBI-1-557, left p2 in lingual (5), labial (6) and occlusal (7) views. 8-10, CBI-1-558, right $\mathrm{m} 1$ in lingual (8), labial (9) and occlusal (10) views. 11-13, CBI-1-559, left m3 in lingual (11), labial (12) and occlusal (13) views. Scale bar equals $5 \mathrm{~mm}$.

occlusal view), one can could conclude that p3 had not started to erupt on that specimen and that dp3 was present when the individual died. The presence of an $\mathrm{m} 2$ associated with a dp3 and dp4 agrees with stage 2 (North American Hyaenodon) and stages 3-4 (European Hyaenodon) of the tooth eruption sequence established by Bastl et al. (2011) for the hyaenodontine Hyaenodon. The distal root situated mesially to those of the latter tooth may correspond either to that of dp2 or to that of p2. NHMUK M 4498 (Hyaenodon exiguus) and NHMUK M 84866 (Hyaenodon filholi) showed that the germs of p3 and p4 are present when the germ of $\mathrm{p} 2$ is developed or when p2 is erupting. If we assume that the early stages of the tooth eruption sequence are somewhat similar in hyaenodonts, we could hypothesize that a dp2 must have been present in $\mathrm{CBI}-1-613$. Whether the $\mathrm{p} 2$ is present or not, it is certain that $\mathrm{CBI}-1-613$ represents a very young hyainailourine individual.

CBI-1-557 (Figure 3.5-7) is identified as a p2 and $\mathrm{CBI}-1-555$ as a p3. As in hyaenodonts, CBI-1557 (p2) is smaller and asymmetric in lateral view compared to $\mathrm{CBI}-1-555$ (p3). The p2 has a simple 

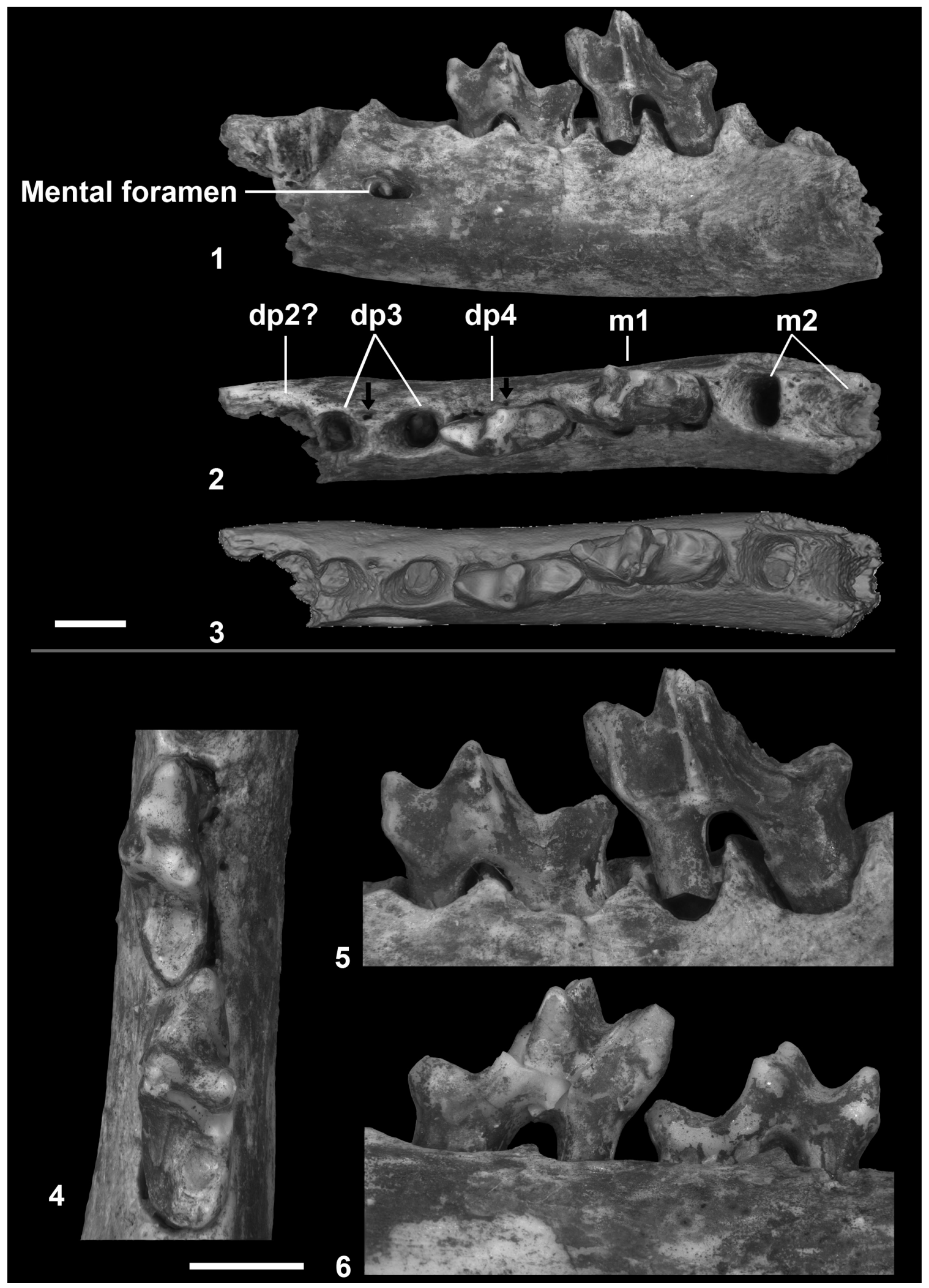

FIGURE 4. Parvavorodon gheerbranti Solé et al., 2014b from Chambi CBI-1 (Tunisia). 1-6, CBI-1-613, left dentary bearing dp4, $\mathrm{m} 1$, alveoli of $\mathrm{dp} 3$ and $\mathrm{m} 2$, and distal alveolus of dp2? in labial (1) occlusal (2), occlusal based on a CTscan reconstruction (3), occlusal close-up (4), labial close-up (5) and lingual close-up (6) views. The black arrows on 2 indicate the two foramina related to the eruption of the permanent teeth (see text). Scale bar equals $2 \mathrm{~mm}$. 

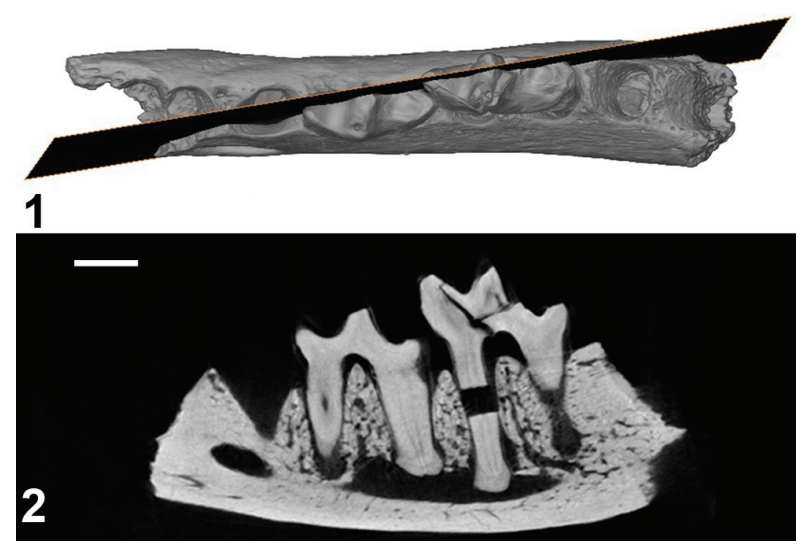

FIGURE 5. CT-scan reconstruction of Parvavorodon gheerbranti Solé et al., 2014b from Chambi CBI-1 (Tunisia); CBI-1-613, left dentary bearing dp4, m1, alveoli of dp3 and m2, and distal alveolus of dp2?. 1, occlusal view; 2, parasagittal slice showing the roots of the $\mathrm{dp} 4$ and $\mathrm{m} 1$. Note the absence of germ below dp3 and dp4. Scale bar equal $2 \mathrm{~mm}$.

crown morphology with a small paraconid, which remains as high as the talonid. The talonid is short and low, and bears only one cusp (hypoconid?) at its distal end.

The $\mathrm{m} 1$, preserved on the dentary $\mathrm{CBI}-1-613$ (Figure 4), is larger than dp4, but its morphology is virtually similar. The paraconid is well located mesially - the paracristid is thus long and secant - and is larger than the metaconid. The metaconid is less distally located than on dp4. The apex of the protoconid is broken, which prevents estimating its height. The talonid cusps are heavily worn; however, the postfossid is narrow as on dp4. A large precingulid is present. Because the isolated molar CBI-1-558 (Figure 3.8-10) is morphologically similar to the CBI-1-613 (m1), we identify the former tooth as a $\mathrm{m} 1$.

The second isolated lower molar (CBI-1-559) is characterized by a high paraconid, which is mesiolingually located, a low and reduced metaconid, and a narrow and mesiodistally elongated talonid (Figure 3.11-13). Only a precingulid is visible. The talonid is worn, which prevents from determining the exact position of the talonid cusps. The presence of a narrower postfossid (but with a wide talonid), a paraconid more lingually located, and a trigonid more opened than on the $\mathrm{m} 1 / \mathrm{m} 2$ specimens described from the Gour Lazib and Chambi, suggest that the CBI-1-559 molar is a m3. These differences in the trigonid and talonid morphologies between the $\mathrm{m} 1-\mathrm{m} 2$ and $\mathrm{m} 3$ are notably exempli-
TABLE 3. Measurements (in $\mathrm{mm}$ ) of the specimens of Parvavorodon gheerbranti Solé et al., 2014b from Chambi. *: fragmentary specimen; ${ }^{* *}$ : based on alveoli.

\begin{tabular}{cccc}
\hline Locus & & $\mathbf{n}$ & OR \\
\hline P3 & L & 1 & 3.48 \\
& W & 1 & 1.65 \\
M1or2 & L & 1 & $3.55^{*}$ \\
& W & 1 & 3.56 \\
\hline dp3 & L & 1 & $3.78^{* *}$ \\
& W & 1 & $1.4^{* *}$ \\
dp4 & L & 1 & 3.8 \\
& W & 1 & 1.44 \\
p2 & L & 1 & 2.76 \\
& W & 1 & 1.14 \\
m1 & L & 1 & 4.48 \\
& W & 1 & 1.86 \\
m3 & L & 2 & $4.11-4.21$ \\
& W & 2 & $1.71-2.45$ \\
\hline DD & & 1 & 5.42 \\
\hline
\end{tabular}

fied by the holotype of the contemporaneous hyaenodont Furodon crocheti (Solé et al., 2014b).

Discussion. The small hyainailourine Parvavorodon was originally described based on two identical lower molars from the Gour Lazib (Solé et al., 2014b). These two molars differ from those of Furodon in being smaller in size despite the fact that they display similar derived secant features (e.g., elongation of the paracristid).

Because the fossils described from Chambi are similar in size and morphology with the two small molars from the Gour Lazib, we refer them to Parvavorodon gheerbranti. This new material from the Eocene of Tunisia testifies to (1) the presence of this small hyaenodont in the late Ypresian (or early Lutetian) of Maghreb, and (2) the secant morphology of its dentition.

The new fossils are also important because they allow recognizing five new dental loci for the species: dp4, P3, p2, M2 (or M1), and m3. Moreover, we describe the first dentary element known for this genus: it corresponds to the oldest dentary element known thus far for a juvenile of Hyaenodonta in Africa. The position of the unique mental foramen present on the dentary is particularly interesting inasmuch as it represents an important feature for discussing the subfamilial classification of Parvavorodon: the distal foramen is actually located below the p3 in hyainailourines, while it is generally located close to or below the roots of $\mathrm{p} 4$ in koholiines (Solé et al., 2009). Because the posi- 


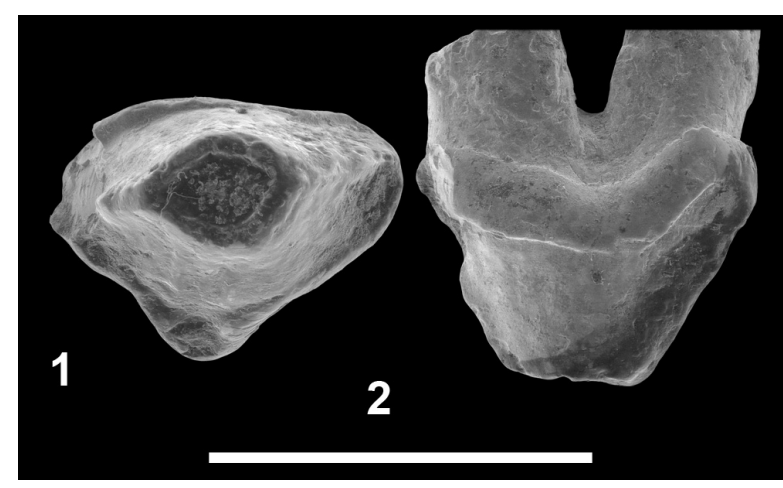

FIGURE 6. Hyainailourinae indet. from Bir el Ater (Algeria). 1-2, UON 84-359, left P3 in occlusal (1) and labial (2) views. Scale bar equals $5 \mathrm{~mm}$.

tion of the distal mental foramen corresponds to the first case, the dentary $\mathrm{CBI}-1-613$ supports the hyainailourine status of Parvavorodon.

As indicated above, in Parvavorodon, the differences observed between the $\mathrm{m} 1-\mathrm{m} 2$ and $\mathrm{m} 3$ are similar to those observed in Furodon. This indicates that the two taxa are probably closely related.

Age and locality. Late Ypresian or early Lutetian; Chambi CBI-1 (Tunisia).

Hyainailourinae indet. Figure 6

Referred specimen. UON 84-359, left P3.

Measurements. $L=4.6 \mathrm{~mm} ; \mathrm{W}=3.6 \mathrm{~mm}$.

Description. The tooth is three-rooted. The paracone is prominent. There is no parastyle. Unfortunately the distal part of the tooth is broken, which prevents from observing the morphology of the metastyle. The lingual root bears a small cusp (? protocone). The enamel is crenulated. The cingula are developed around the tooth.

Discussion. The small size of the lingual cusp and absence of a parastyle indicate that UON 84-359 is not a P4. However, this tooth is three-rooted and bears a small lingual cusp, two characters which allow identifying it as a P3.

The presence of a third root on P3 is often observed in hyainailourines - and in some limnocyonines (Morlo and Gunnell, 2005). For instance, it has been observed in the following Eocene-Oligocene taxa: Pterodon africanus Andrews, 1903, Pterodon syrtos Holroyd, 1999, Paroxyaena Martin, 1906, and Parapterodon Lange-Badré, 1979. The presence of this root is related to the development of the lingual cusp, which is analogous to the protocone of P4. This structure is notably welldeveloped in Paroxyaena (Lange-Badré, 1979). It is worth noting that the development of the cingula is found in the European Paroxyaena, but the P3s of the latter are much larger than UON 84-359. As a result, we tentatively refer UON 84-359 to the Hyainailourinae. However, because the taxon of Bir el Ater is only documented by this tooth, we referred it as Hyainailourinae indet. pending additional material.

Age and locality. Latest Bartonian or earliest Priabonian; Bir el Ater (Algeria).

Subfamily TERATODONTINAE Savage, 1965

MASRASECTOR Simons and Gingerich, 1974

Type Species. Masrasector aegypticum Simons and Gingerich, 1974

Masrasector cf. ligabuei Crochet, Thomas, Roger, Sen, and Al-Sulaimani, 1990

Figure 7

Referred specimens. UON 84-360, right M1or2; UON 84-361, right M3; UON 84-397, right p3.

Measurements. UON 84-360, L > $3.57 \mathrm{~mm}, \mathrm{~W}>$ $5.55 \mathrm{~mm}$; UON 84-361, L > $2.73 \mathrm{~mm}, \mathrm{~W}>5.37$ $\mathrm{mm}$; UON 84-397, L $=5.1 \mathrm{~mm} ; \mathrm{I}=2.7 \mathrm{~mm}$.

Description. UON 84-360 is characterized by the presence of the metacone and paracone that are separated at mid-height (Figure 7.1-2). The base of the metacone is larger than that of the paracone. The parastyle and metastyle areas are unfortunately broken. The protofossa is large but heavily worn. The metaconule and paraconule cannot be distinguished but were surely present based on the size of the protofossa and the height of the preprotocrista and postprotocrista. The protocone is prominent. No cingulum is visible. It is currently impossible to determine whether UON 84-360 corresponds to a M1 or a M2.

UON 84-361 is only a protofossa (Figure 7.34). Its transversal elongation and mesiodistal compression allow considering it as a fragment of M3. The protocone is well-developed. The paraconule and metaconule are well-defined; the former is the larger. There is a large precingulum along the protofossa.

UON 84-397 is a lower premolar (Figure 7.57) that was probably blunt, as the condition observed in Masrasector species (Peigné et al., 2007; Lewis and Morlo, 2010). Its protoconid is wide but heavily worn. There is no appreciable development of a paraconid, but the presence of a lingual precingulid could indicate the presence of a small paraconid. The area of the talonid is characterized by the presence of a postcingulid in both labial and lingual views. The absence of a wide postfossid, characterized by the presence of an entoconid, implies that the specimen better corre- 


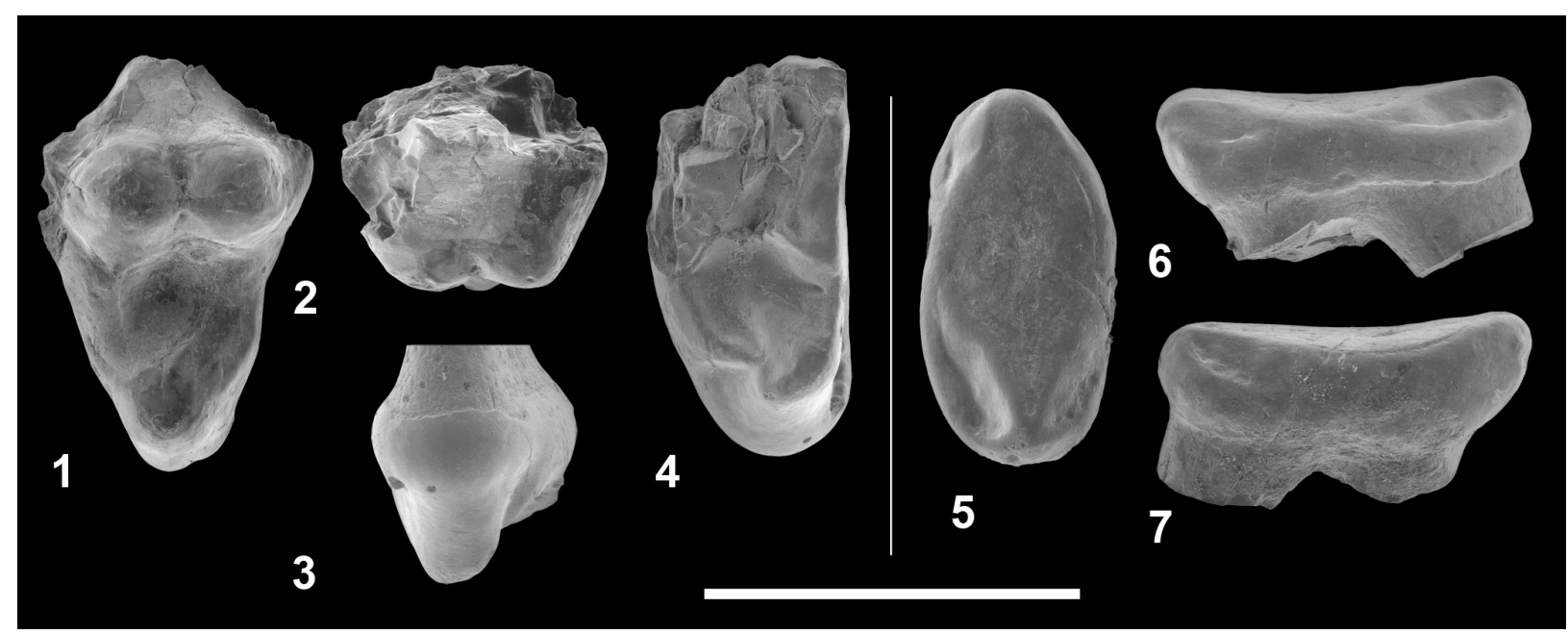

FIGURE 7. Masrasector cf. ligabuei from Bir el Ater (Algeria). 1-2, UON 84-360, right M1or2 in occlusal (1) and labial (2) views. 3-4, UON 84-361, right M3 in lingual (3) and occlusal (4) views. 5-7, UON 84-397, right p3 in occlusal (5), lingual (6) and labial (7) views. Scale bar equals $5 \mathrm{~mm}$.

sponds to a p3; the large size of the talonid excludes a $\mathrm{p} 2$ position.

Discussion. The well-marked separation of the paracone and metacone on UON 84-360 (M1or2) and the large size of the protofossa suggest that this specimen is better referred to the Teratodontinae rather than to the Hyainailourinae. The presence of the precingulum on UON 84-361 (M3) supports an attribution to the teratodontines for this specimen. Although this specimen is worn, the UON 84-397 premolar (p3) is clearly similar to those of the Masrasector species from the Fayum (Jebel Qatrani Fm., L-41, Priabonian; Jebel Qatrani Fm., Quarries A, E, G, I, M, Rupelian; Holroyd, 1994) notably because the surface of wear is flat and horizontal, as it is observed in Masrasector aegypticum (Jebel Qatrani Fm., Quarry G, Rupelian) (Simons and Gingerich, 1974). The upper molars are also morphologically similar to the molars known for Masrasector (Crochet et al., 1990; Holroyd, 1994). Finally, the relative large size of p3 with respect to the upper molar size agrees with the attribution of this material to Masrasector.

The three specimens thus support the presence of a teratodontine (Masrasector) in the Algerian locality of Bir el Ater. The sizes of the specimens - notably the $p 3$, which is the most complete tooth - agree with that of the specimens of Masrasector ligabuei, the medium-sized species of the genus among the Fayum fauna (Jebel Qatrani Fm., Quarries A, E, Rupelian) (Holroyd, 1994, tables 5.1 and 5.2). We refer the three specimens from Bir el Ater as Masrasector cf. ligabuei, pending the discovery of better preserved material. Despite this lack of clear specific attribution, it is important to note that the specimens from Bir el Ater are the oldest to be known for the teratodontine genus Masrasector.

The oldest teratodontine so far known is Glibzegdouia tabelbalaensis from the Gour Lazib area (Solé et al., 2014b). UON 84-360 molar is however not larger than the fragmentary M2 (HGL 10-15; L $=6.93 \mathrm{~mm}$ ) recently described from the older locality of the Gour Lazib and attributed to G. tabelbalaensis (Solé et al., 2014b). Unfortunately, it is impossible to compare the morphology of the two specimens because HGL 10-15 corresponds only to a labial fragment.

Age and locality. Latest Bartonian or earliest Priabonian; Bir el Ater (Algeria).

\section{Teratodontinae indet.}

Figure 8

Referred specimen. CBI-1-614, right $\mathrm{P} 4$.

Measurements. $L=3.56 \mathrm{~mm} ; \mathrm{W}=3.92 \mathrm{~mm}$.

Description. CBI-1-614 is identified as a P4 because of the presence of a large protocone. The latter is bulbous and as long as the paracone. The paracone is elongated mesiodistally. The parastyle and metastyle are poorly developed and low; the metastyle is however slightly more developed than the parastyle. A centrocrista was possibly present. No cingulum is visible.

Discussion. CBI-1-614 recalls the P4 of Metasinopa napaki Savage, 1965, Anasinopa leaki Savage, 1965 and Teratodon spekei Savage, 1965, as well as that of the "proviverrines" - referred as Ter- 


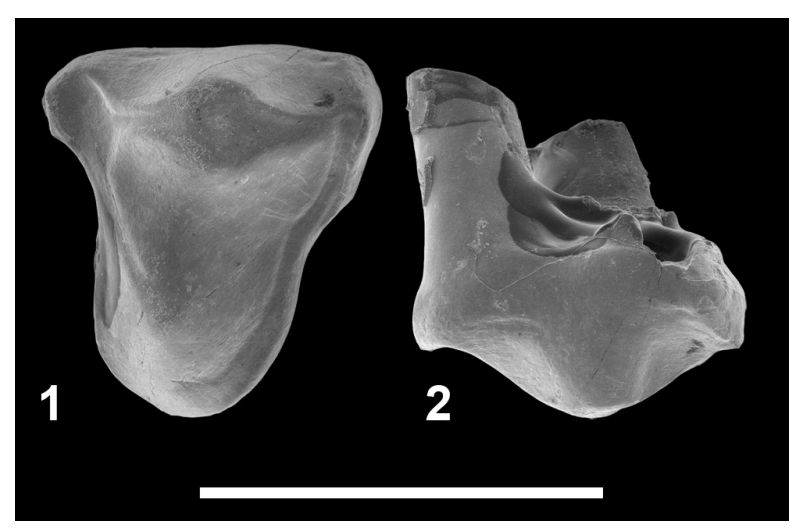

FIGURE 8. Teratodontinae indet. 1 from Chambi CBI-1 (Tunisia). 1-2, CBI-1-614, right P4 in occlusal (1) and labial (2) views. Scale bar equals $5 \mathrm{~mm}$.

atodontinae sensu Solé et al. (2014b) - described by Holroyd in her Ph.D. Thesis (1994). This is particularly shown in the presence of a large protocone and a poorly developed parastyle - and possible presence of a centrocrista. These features distinguish the P4 of the teratodontines from that of the contemporaneous hyainailourines. Indeed, the protocone is small and the metastyle is larger on the P4 of the latter.

We estimated the measurements expected for the P4 of Glibzegdouia tabelbalaensis based on a comparison with the P4 and m1 of Anasinopa leaki and $\mathrm{m} 1$ of Glibzegdouia tabelbalaensis: its length should be $7.2 \mathrm{~mm}$, while the expected width should be $6.7 \mathrm{~mm}$. As such, CBI-1-614 appears to be twice as small as the P4 expected for the sole teratodontine known at that time.

This discovery implies that the teratodontines were possibly diversified in the late Ypresian (or early Lutetian) of North Africa. This is similar to what is known for the hyainailourines (see above) (Table 1).

The Namibian upper molar (BC 2'08) recently described by Pickford et al. (2008) as a Proviverrinae genus and species indet. - considered as a teratodontine by Solé et al. (2014b) - is one of the smallest hyaenodont ever recorded in Africa (Pickford et al., 2008). However, the specimen is markedly smaller $(L=2.97 \mathrm{~mm}$; $W=2.33 \mathrm{~mm})$ than $C B I-$ 1-614, supporting as well a diversity of the teratodontines during the late Ypresian-early Lutetian.

Age and locality. Late Ypresian or early Lutetian; Chambi CBI-1 (Tunisia).

\section{GENERAL DISCUSSION}

\section{Biostratigraphic Implications}

Based on biostratigraphic data (mammals and charophytes), Hartenberger et al. (1997, 2001) envisaged that the locality of Chambi (Tunisia) is Ypresian in age and possibly older than those from the Gour Lazib complex (Algeria). However, based on recent better substantiated biostratigraphic and magnetostratigraphic data, a contemporaneity between both localities have been proposed (Tabuce et al., 2011; Coster et al., 2012; Marivaux et al., 2015; Ravel et al., 2015, in press), i.e., dated as late Ypresian or early Lutetian, between 49 and 45 m.y.

Some of the hyaenodont fossils described here indicate the presence in Chambi of the two hyainailourines - Furodon and Parvavorodon that have been previously recognized in the Gour Lazib (Solé et al., 2014b). This implies that these genera were present almost in the entire Maghreb at that time (Figure 1.1). Surprisingly, the unique taxon from Chambi, which is herein attributed to the Teratodontinae, is clearly smaller than Glibzegdouia from the Gour Lazib: this discovery implies that teratodontines in North Africa were - possibly - as diversified as hyainailourines. Despite this difference, the new Tunisian fossils strengthen support for the hypothesis of a similar age of the two fossiliferous sites.

The fossil locality of Bir el Ater has yielded few hyaenodonts compared with Chambi. Nonetheless, we can definitively conclude on the presence of both Teratodontinae and Hyainailourinae in this late Bartonian or early Priabonian locality. The poor preservation of the fossils and their scarcity do not provide pieces of information regarding the precise age of that Algerian mammal-bearing locality.

In an abstract, Borths et al. (2010) presented a new taxon from the earliest Priabonian ( 37 m.y.) Birket Qarun Locality 2 (BQ-2; Fayum Depression, Egypt). He indicated that this taxon is close to Masrasector from the Fayum Depression and Oman (Table 1), and Kyawdawia from the Pondaung Formation (late Middle Eocene; Myanmar). As quoted by Seiffert et al. (2008, p. 81), "the mammalian faunas from BQ-2 and Bir el Ater are more similar to each other than they are to any other Afro-Arabian Paleogene fauna." Consequently, the fossils found in Bir el Ater that we refer as Masrasector cf. ligabuei are possibly close to those currently studied by $M$. Borths. This could support the presence of Masrasector in both Algeria and Egypt at that time. 


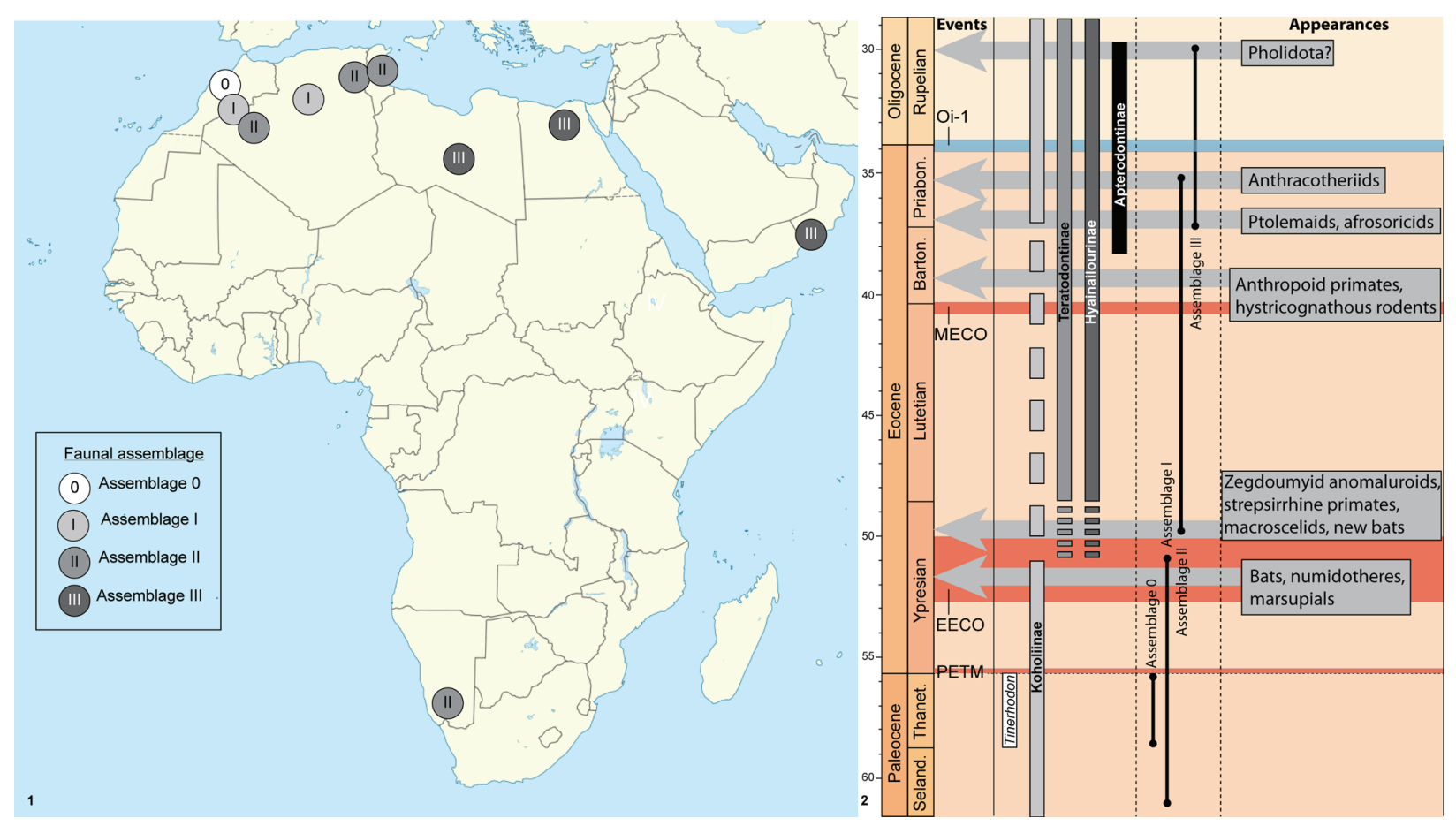

FIGURE 9. 1, geographic distribution of the Faunal Assemblages (see text). 2, stratigraphic distribution of Tinerhodon and hyaenodont subfamilies in Africa during Paleocene and Eocene, and of the faunal assemblages regarding the main climatic events and mammal appearances. Note the gap in the fossil record of the Koholiinae. Abbreviations: Barton.= Bartonian; EECO: Early Eocene Climatic Optimum; MECO: Middle Eocene Climatic Optimum; PETM: Paleocene-Eocene Thermal Maximum; Priabon.= Priabonian; Seland.= Selandian; Thanet.= Thanetian.

The locality of Dur at-Talah (late Bartonian or Priabonian; Libya) is also considered to be close in age to Bir el Ater based on its mammal fauna (Seiffert, 2010). However, Sanders and Seiffert (2014) and Sallam and Seiffert (2016) indicated that the proboscideans and rodents from Dur at-Talah provide better evidence for a Priabonian-Rupelian than a Bartonian age for this site. In any case, the Libyan locality yielded apterodontines (Grohé et al., 2012), but so far no hyainailourine or teratodontine (Table 1). As the Apterodontinae are unknown in both Bir el Ater and BQ-2 (Table 1), the carnivorous fauna of Dur at-Talah is clearly different from that of the Algerian and Egyptian localities despite a probable proximity in time. Nonetheless, it is also possible that several hyaenodonts from Dur atTalah remains so far undescribed.

\section{Evolution of the African hyaenodonts during the Paleocene and Eocene}

The Figure 9 summarizes the geographic and temporal distributions of the hyaenodonts in Africa. The hyaenodonts are mostly known in Northern Africa, but the faunas are not similar in this area and during Eocene times (Table 1). Considering this, we established four faunal assemblages based on their respective carnivorous taxa (Figure 9.1). The present approach is a preliminary approximation, because it is clear that the fossil record of the Paleocene and Eocene of Africa remains still incomplete.

The "Assemblage 0 " is characterized by the presence of Tinerhodon and taxa that display similarities with the Proviverrinae sensu Polly (1996); Tinerhodon is also morphologically close to the Proviverrinae sensu Solé (2013) (Solé et al., 2015). This assemblage is so far very restricted because it only concerns the Paleocene localities of the Ouarzazate Basin (Morocco; Gheerbrant, 1995); it thus will not be further discussed in the present paper.

The "Assemblage I" is characterized by the koholiines, which are otherwise the only creodont representatives of the Paleocene-Eocene localities of the Ouled Abdoun Basin (Morocco) and El Kohol (Algeria).

The "Assemblage II" is based on the common presence of the hyainailourines and teratodontines. This group includes the Algerian localities of the Gour Lazib and Bir el Ater, the Tunisian locality of Chambi, and the Black Crow locality from Sperrgebiet (Namibia). 
The "Assemblage III" is defined by the appearance of the apterodontines and "reappearance" of the koholiines in Northern Africa. The locality of Dur at-Talah (Libya) is presently original because the apterodontines are the only carnivorous mammals recorded (see above) (Figure 9.2; Table 1). This assemblage also includes the localities of Taqah in Oman and from the Fayum Depression in Egypt (Birket Qarun Locality 2, Jebel Qatrani Fm., Qasr el-Sagha Fm.). The presence of the teratodontines and hyainailourines in this assemblage is reminiscent of "Assemblage II" (Figure 9.2; Table 1).

The "Assemblage I" clearly predates the "Assemblage II" when the four assemblages are analysed and considering the stratigraphic sequence (Figure 9.2). The koholiines, which characterized the assemblages I and III, are recorded in the Paleocene, Ypresian, and Priabonian of North Africa. As a result, there is an important gap (= entire middle Eocene) in their fossil record; as a whole the African mammalian fossil record at that time is very poor. During almost the entire middle Eocene, the carnivorous fauna was composed only by the hyainailourines and teratodontines (Figure 9.2).

The "Assemblage III" is characterized by an important increase regarding the diversity of hyaenodonts - and thus of the second faunal assemblage. This assemblage appears at the end of the Eocene and represents the last assemblage here recognized (Figure 9.2). This assemblage extends from the Late Eocene to the Rupelian (early Oligocene), where the four typical hyaenodont subfamilies are recorded (e.g., Holroyd, 1994, 1999; Lewis and Morlo, 2010).

The geographic distribution of these assemblages is also intriguing. The "Assemblage I" and "Assemblage II" are more or less located in the same area that encompasses - from West to East - Morocco, Algeria, and Tunisia (Figure 9.1), while the third one is only situated in the eastern part of North Africa (Libya and Egypt) (Figure 9.1). Furthermore, the "Assemblage II" (Hyainailourinae + Teratodontinae) is also recorded in the Southern Africa (Namibia) (Figure 9.1). However, these differences certainly result from both stratigraphic and geographic biases in the African fossil record.

The present survey of the composition of the African communities of carnivores during the Paleogene needs to be faced to what is known concerning the climate and other African mammal faunas during this period. Unfortunately, the evolution of several placental mammals in Africa is so far poorly understood due to gaps in the fossil record.

In general, the African continental climate appears to have been generally wet and warm during the Paleocene and especially the Eocene (Feakins and Demenocal, 2010), but, as evidenced by Bolle et al. (1999), climatic events such as the "Paleocene-Eocene Thermal Maximum" (= PETM) would have had a significant impact on nearby continental environments, notably in resulting in a more arid climate. There was an important increase of the greenhouse effect during the "Early Eocene Climatic Optimum" (= EECO; 53-50 m.y.) (Zachos et al., 2008) (Figure 9.2). Furthermore, the coasts of North Africa are mostly covered by a large marine transgression of a tropical sea during the early Paleogene (65-50 m.y.) (Partridge, 2010). The EECO was followed by a long-term cooling (Zachos et al., 2001).

A more abrupt cooling (Oi-1; 34.1-33.6 m.y.), which has affected both marine and terrestrial ecosystems (Hren et al., 2013), is recorded at the Eocene-Oligocene Boundary (EOB; Figure 9.2) (Zachos et al., 2001). Moreover, at the beginning of the Oligocene, an Antarctic ice sheet began to develop (Zachos et al., 1992, 2001). The glaciation was initiated, after climatic preconditioning, by an interval when the Earth's orbit of the Sun favoured cool summers (DeConto and Pollard, 2003). These events notably resulted in the increase of aridity in southern Africa (Feakins and Demenocal, 2010). As a result, the late Eocene (Bartonian and Priabonian) and Oligocene periods illustrate a transition from "greenhouse" state to "icehouse" conditions. The Fayum sequence includes a major unconformity just above Quarry L-41; Gingerich (1993) and Seiffert (2006) considered that it results from erosion associated with a rapid drop in sea level occurring in the earliest Oligocene. The earliest Oligocene ice-volume changes and cooling event indeed lowered sea level and are possibly responsible for this eustatic fall (Miller et al., 2008).

As indicated above, the Paleocene and early Eocene faunas are dominated by the "Assemblage I" where only the koholiines are known (Gheerbrant et al., 2006; Solé et al., 2009) (Figure 9). In these faunas, the proboscideans are also abundant and diversified (Gheerbrant et al., 2002). Sanders et al. (2010) remarked that the phosphathere and daouithere proboscideans, which are recorded in the fauna of the Ouled Abdoun basin in Morocco ("Assemblage I"), are succeeded by numidotheres during the Ypresian. Numidotherium is recorded in El Kohol, Algeria (Mahboubi et al., 1986). This 
modification of the proboscidean fauna is concomitant with the first occurrence of bats (Ravel et al., 2011b), hyracoids (Court and Mahboubi 1993; Gheerbrant et al., 2003, Benoit et al., 2016), and of possible marsupials (Crochet, 1984) in the African fossil record (Figure 9.2). The recent proposed age of El Kohol ( 51-52 m.y.) by Coster et al. (2012) implies that this locality is situated in the warmest period of the EECO (Figure 9.1). Despite these faunal modifications, the hyaenodonts do not seem to have been affected: the koholiine Koholia is actually the only carnivorous mammal known in El Kohol.

In fact, the modification of the African hyaenodont fauna occurred after the EECO (Figure 9.2): the koholiines are replaced by the teratodontines and hyainailourines. Moreover, the faunas of Chambi and the Gour Lazib areas also provide the oldest African fossils of zegdoumyid anomaluroids (Vianey-Liaud et al, 1994; Marivaux et al., 2011, 2015), strepsirrhine primates (azibiids and djebelemurines) (Tabuce et al., 2009; Marivaux et al., 2013), and macroscelids (Tabuce et al., 2007; Adaci et al. 2007). In addition, Ravel et al. (2011b) remarked a modification of the bat fauna between El Kohol and Chambi (Figure 9.2).

Solé et al. (2014b) proposed that the teratodontines and hyainailourines originated in Africa, while Rana et al. (2015) hypothesized that they dispersed from South Asia to Africa between 51.9 (EI Kohol) and 45.5 m.y. (Glib Zegdou) together with rodents and strepsirrhine primates. Recent studies indicate that the ancestors of zegdoumyid anomaluroids and strepsirrhine primates may have colonized Africa from Europe or Eurasia, sometime during the Ypresian or even at the earliest Ypresian, due to the climatic optimum recorded at the Paleocene/Eocene transition (PETM; Marivaux et al., 2013, 2015). In any case, due to their diversity and widespread distribution in Africa as early as the late Ypresian or early Lutetian, it may be expected that these mammals have experienced an earlier phase of diversification in Africa during the Ypresian. Such a scenario is also conceivable for the teratodontines and hyainailourines.

Whatever are the exact geographic origins and early evolution of these rodents, hyaenodonts, and primates, it is clear that there was an important evolution of the North African mammal fauna after the EECO. For instance, the mammalian faunas from Chambi and Gour Lazib document the first adaptive radiation of hyracoids (Tabuce et al., 2011). Consequently, the faunal modification that affected hyaenodonts probably fit with a more gen- eral pattern that corresponds to a large modification of the mammalian faunas in the Maghreb, possibly due to inter- or intracontinental dispersals. This faunal turnover probably results from a modification of the African climate (cooling period) and vegetation (see above). Besides, the importance of the climate on Eocene mammals has been recently exemplified by Woodburne et al. (2009) who, based on the mammal fossil record, evidenced the existence in North America of a major faunal reorganization following the EECO event (Bridgerian Crash).

The presence of the fauna of "Assemblage II" in Namibia (Figure 9.1) is interesting because it indicates, as noticed by Pickford et al. (2008), that the fauna recorded in North Africa may have rapidly dispersed into the opposite extremity of Africa without significant delays. The mammals possibly dispersed along the Atlantic coasts through environments dominated by the tropical Asian palm Nypa. As summarized by Jacobs et al. (2010), Nypa and other palms were present along Africa's coasts at low latitudes in the Paleocene and Eocene, probably related to the marine transgression. Nevertheless, the two taxa from the latter fossiliferous site are smaller than those from Northern Africa and support the existence of endemism as proposed by Pickford et al. (2008).

The early Bartonian is notably characterized by the first appearances of hystricognathous rodents and anthropoid primates (Figure 9.2); the temporal framework of this event was recently improved thanks to the discovery of the fossil locality of Djebel el Kébar, Tunisia (Bartonian, 39.5 m.y.; Marivaux et al., 2014a, 2014b). These two groups likely invaded Africa from Asia. Because they appear in the fossil record only shortly after the middle Eocene global warming, the "Middle Eocene Climatic Optimum" (MECO), Marivaux et al. (2014a, 2014b) questioned the role of this climatic event on this dispersal event. The hyaenodonts do not seem to have been affected by this important increase of the mammal diversity and the climatic modifications.

The Priabonian of North Africa is characterized by several new dispersals of mammals and diversification of some of those that were already present. These are: dispersal of the embrithopods into Northern Africa (Pickford et al., 2008; Vialle et al., 2013), diversification of the proboscideans (Delmer, 2009; Sanders et al., 2010), hystricognathous rodents (Sallam et al., 2009, 2011, 2012; Marivaux et al., 2014a), anthropoid primates (Jaeger et al., 2010; Seiffert, 2010; Marivaux et al., 
2014b), and appearances of the ptolemaïds (Cote al., 2007) and possibly of the anthracotheriid artiodactyls (Holroyd et al., 1996) (Figure 9.2). The latter probably dispersed from Laurasia (southeastern Asia?) into Africa (Holroyd et al., 2010; Lihoreau et al., 2015), while the ptolemaïds, if they are afrotherians may have an ancient African origin (Cote al., 2007; Seiffert, 2007a).

This latter period of faunal enrichment clearly matches with the diversification of the hyaenodonts in Africa, which is well exemplified by the appearance of the Apterodontinae (these latter being very original among hyaenodonts). As discussed by Grohé et al. (2012), they possibly had a semiaquatic lifestyle. The restricted distribution of this subfamily could be explained following two hypotheses that could be complementary: (a) the apterodontines originated in this area (this is supported by their diversity in Dur at-Talah and in Egypt), and (b) the local environment favoured these semiaquatic predators. Regarding this question, it is worth noting that Liu et al. (2008) have proposed that the proboscideans Barytherium and Moeritherium from the Priabonian of the Birket Qarun localities (Fayum Depression) were at least semiaquatic and lived in freshwater swamp or riverine environments, and grazed on freshwater vegetation. This is mentioned here because these two genera are indeed also known in Qasr el Sagha and Dur atTalah (Sanders et al., 2010; Sanders and Seiffert, 2014), where the Eocene apterodontines have been found (Table 1).

The reappearance of koholiines in the fauna of the Fayum ("Assemblage III") implies that the koholiines did not disappear from Africa but may have had a different or restricted geographic distribution during the Lutetian and Bartonian; they may have been present in the inland territories.

The Priabonian also corresponds to an extension of the distribution of both the hyainailourines and teratodontines toward the East of the Maghreb and Egypt. This homogenisation of the carnivorous fauna in Egypt could have started during the earliest Priabonian if the presence of teratodontine Masrasector in BQ-2 is confirmed. The presence of fauna characterizing the "Assemblage II" in Bir el Ater could result either from regional differences (stratification of the environments in Northern Africa) or could be due to a taphonomic bias.

The "Assemblage II" and "Assemblage III" have a very long stratigraphic distribution indicating of stable environment and fauna. Moreover, it seems that the "Assemblage III" did not suffer from the abrupt cooling (Oi-1) that occurred around the
Eocene-Oligocene boundary. The teratodontine Masrasector is a good illustration because it is recorded from the Priabonian (L-41) and Rupelian (Quarries A and E) localities in the Jebel Qatrani $\mathrm{Fm}$. In general, the mammals from the Fayum area were differentially affected by this climatic deterioration: for instance, Seiffert (2007b, 2010) noted that this transition is marked by the local extinction (i.e., from Northern Africa) of several primate groups (Galagidae, Plesiopithecidae, Djebelemurinae, and Adapidae) and of one subfamily of Macroscelidea (Herodotiinae).

The "Assemblage III" ends during the Rupelian with a decrease of the hyaenodont diversity: the semi-aquatic apterodontines, which has dispersed into Europe at that time (Lange-Badré and Böhme, 2005), actually disappeared from Africa.

\section{CONCLUSION}

The African fossil record of hyaenodonts during the Paleocene-Eocene is scarce. Only 10 fossiliferous sites have contributed to our knowledge of this group. These data have, however, attracted much attention of the paleomammologists because hyaenodonts have possibly originated in Africa (Gingerich and Deutsch, 1989; Gheerbrant, 1995; Gheerbrant et al., 2006; Solé et al., 2009; Solé et al., 2014b) and were the only carnivorous mammals in Africa until the arrival of Carnivora (Late Oligocene; 23 m.y.) (Rasmussen and Gutierrez, 2009).

The present study shows that the evolution of these mammals in Africa is furthermore important for understanding the global dynamic of mammal evolution in Africa. Our analysis of the hyaenodont evolution in Africa allows recognizing important reorganisations of the carnivorous faunas in the Maghreb during the Eocene. One of these faunal changes seems to be due to the cooling that succeeded to the EECO event; in contrast, the abrupt cooling event Oi-1 had seemingly no drastic effect on the hyaenodont fauna.

The data concern only restricted areas (e.g., Maghreb), which obscures our understanding of the general evolutionary history of hyaenodonts in Africa. The discovery of new Paleocene and Eocene fossils in Africa and by describing them, as in the present article, is crucial in this framework.

\section{ACKNOWLEDGMENTS}

The authors thank J.-L. Hartenberger (ISE-M, Montpellier) and J.-J. Jaeger (IPHEP, Poitiers) for discussion about Chambi and Bir el Ater sites, 
respectively; B. Marandat, A.-L. Charruault and S. Unal (ISE-M, Montpellier) for their substantial contribution in the extraction and preparation of the fossil specimens from Chambi CBI-1; and J. Cillis (IRSNB) to have taken the S.E.M. images. Finally, many thanks to R. Lebrun (ISE-M, Montpellier, France), the Montpellier RIO Imaging (MRI) and the LabEx CeMEB for access to the $\mu$ CT-scanning station Skyscan 1076 (ISE-M, Montpellier, France). We warmly thank E. Gheerbrant (CNRS-MNHN, Paris) for the fruitful discussions before and during the 74th Annual Meeting of the Society of Vertebrate Paleontology (Berlin, Nov. 2014). rays. We wish to thank $\mathrm{K}$. Bastl and one anonymous reviewer for valuable comments and discussions about the tooth eruption sequence that led to improvement of this manuscript. This work was supported by the ANR-ERC PALASIAFRICA Program (ANR-08-JCJC-0017), a grant from the Conseil Scientifique (CS) of the Université Montpellier 2 (UM2), the ONM of Tunis (AC-1785), and by the BR/121/A3/PALEURAFRICA program ( $F$. Solé) of the Federal Science Policy Office of Belgium.

\section{REFERENCES}

Adaci, M., Tabuce, R., Mebrouk, F., Bensalah, M., Fabre, P.-H., Hautier, L., Jaeger, J.-J., Lazzari, V., Mahboubi, M., Marivaux, L., Otero, O., Peigné, S., and Tong, H. 2007. Nouveaux sites à vertébrés paléogènes dans la région des Gour Lazib (Sahara Nord-occidental, Algérie). Comptes Rendus Palevol, 6:535-544.

Andrews, C.W. 1903. Notes on an expedition to the Fayum, Egypt, with descriptions of some new mammals. Geological Magazine (Decade IV), 10:337-343.

Andrews, C.W. 1906. A descriptive catalogue of the Tertiary Vertebrata of the Fayûm, Egypt. British Museum (Natural History), London.

Bastl, K., Morlo, M., Nagel, D., and Heizmann, E. 2011. Differences in the tooth eruption sequence in Hyaenodon ("Creodonta", Mammalia) and implications for the systematics of the genus. Journal of Vertebrate Paleontology, 31:181-192.

Bastl, K., Nagel, D., and Peigné, S. 2014. Milk tooth morphology of small-sized Hyaenodon (Hyaenodontidae, Mammalia) from the European Oligocene - evidence of a Hyaenodon lineage in Europe. Palaeontographica $A, 303: 61-84$.

Beard, K.C. 1998. East of Eden: Asia as an important centre of taxonomic origination in mammalian evolution. Bulletin of the Carnegie Museum of Natural History, 34:5-39.

Benoit, J., Adnet, S., El Mabrouk, E., Khayati, H., Ali, M.B.H., Marivaux, L., Merzeraud, G., Merigeaud, S., Vianey-Liaud, M., and Tabuce, R. 2013b. Cranial Remain from Tunisia Provides New Clues for the Origin and Evolution of Sirenia (Mammalia, Afrotheria) in Africa. PloS ONE 8, e54307. doi:10.1371/journal.pone. 0054307

Benoit, J., Crochet, J.-Y., Mahboubi, M., Jaeger, J.-J., Bensalah, M., Adaci, M., and Tabuce, R. 2016. New material of Seggeurius amourensis (Paenungulata, Hyracoidea), including a partial skull with intact basicranium. Journal of Vertebrate Paleontology 36, e1034358-1034352.

Benoit, J., Orliac, M., and Tabuce, R. 2013a. The petrosal of the earliest elephant-shrew Chambius (Macroscelidea: Afrotheria) from the Eocene of Djebel Chambi (Tunisia) and the evolution of middle and inner ear of elephant-shrews. Journal of Systematic Palaeontology, 11:907-923.

Bolle, M.P., Adatte, T., Keller, G., Von Salis, K., and Burns, S. 1999. The Paleocene-Eocene transition in the southern Tethys (Tunisia): Climatic and environmental fluctuations. Bulletin de la Société Géologique de France, 170:661-680.

Borths, M.R., Seiffert, E.R., Goodenberger, K., and Simons, E. 2010. The oldest Fayum Creodont: Dental and Humeral morphology of a new proviverine hyaenodontid from the earliest Late Eocene of Egypt. Journal of Vertebrate Paleontology, Program and Abstracts, 2010, 63A.

Coiffait, P.-E., Coiffait, B., Jaeger, J.-J., and Mahboubi, M. 1984. Un nouveau gisement à mammifères fossiles d'âge Éocène supérieur sur le versant Sud des Nementcha (Algérie orientale): découverte des plus anciens rongeurs d'Afrique. Comptes Rendus de l'Académie des Sciences. Série 2, 299:893-898.

Coster, P., Benammi, M., Mahboubi, M., Tabuce, R., Adaci, M., Marivaux, L., Bensalah, M., Mahboubi, S., Mahboubi, A., Mebrouk, F., Maameri, C., and Jaeger, J.-J. 2012. Chronology of the Eocene continental deposits of Africa: Magnetostratigraphy and biostratigraphy of the El Kohol and Glib Zegdou Formations, Algeria. Geological Society of America Bulletin, 124:1590-1606.

Cote, S., Werdelin, L., Seiffert, E.R., and Barry, J.C. 2007. Additional material of the enigmatic Early Miocene mammal Kelba and its relationship to the order Ptolemaiida. Proceedings of the National Academy of Sciences, 104:5510-5515.

Court, N. and Hartenberger, J.L. 1992. A new species of the hyracoid mammal Titanohyrax from the Eocene of Tunisia. Palaeontology, 35:309-317.

Court, N. and Mahboubi, M. 1993. Reassessment of lower Eocene Seggeurius amourensis: aspect of primitive dental morphology in the mammalian order Hyracoidea. Journal of Paleontology, 67:889-893.

Crochet, J.-Y. 1984. Garatherium mahboubii nov. gen., nov. sp., marsupial de l'Éocène inférieur d'El Kohol (Sud-Oranais, Algérie). Annales de Paléontologie, 70:275-294.

Crochet, J.-Y. 1988. Le plus ancien Créodonte africain: Kohalia altlasense nov. gen., nov. sp.(Eocène inférieur d'El Kohol, Atlas saharien, Algérie). 
Comptes Rendus de l'Académie des Sciences. Série 2, 307:1795-1798.

Crochet, J.-Y., Thomas, H., Roger, J., Sen, S., and AlSulaimani, Z. 1990. Première découverte d'un crédonte dans la péninsule Arabique: Masrasector ligabuei nov. sp. (Oligocène inférieur de Taqah, formation d'Ashawq, sultanat d'Oman). Comptes rendus de l'Académie des Sciences, Série 2, 311:14551460.

de Bonis, L., Jaeger, J.-J., Coiffait, B., and Coiffait, P.-E. 1988. Découverte du plus ancien primate catarrhinien connu dans l'Eocène supérieur d'Afrique du Nord. Comptes Rendus de l'Académie des Sciences, Série 2, 306:929-934.

DeConto, R.M. and Pollard, D. 2003. Rapid Cenozoic glaciation of Antarctica induced by declining atmospheric CO2. Nature, 421:245-249.

Delmer, C. 2009. Reassessment of the generic attribution of Numidotherium savagei and the homologies of lower incisors in proboscideans. Acta Palaeontologica Polonica, 54:561-580.

Delmer, C., Mahboubi, M., Tabuce, R., and Tassy, P. 2006. A new species of Moeritherium (Proboscidea, Mammalia) from the Eocene of Algeria: new perspectives on the ancestral morphotype of the genus. Palaeontology, 49:421-434.

Feakins, S.J. and Demenocal, P.B. 2010. Global and African Regional Climate during the Cenozoic, p. 4546. In Werdelin, L. and Sanders W.J. (eds.), Cenozoic Mammals of Africa. University of California Press, Berkeley.

Gheerbrant, E. 1995. Les mammifères paléocènes du Bassin d'Ouarzazate (Maroc). III. Adapisoriculidae et autres mammifères (Carnivora, ? Creodonta, Condylarthra,? Ungulata et incertae sedis). Palaeontographica A, 2374:39-132.

Gheerbrant, E., larochene, M., Amaghzaz, M., and Bouya, B. 2006. Early African hyaenodontid mammals and their bearing on the origin of the Creodonta. Geological Magazine, 143:475-489.

Gheerbrant, E., Sudre, J., Cappetta, H., larochéne, M., Amaghzaz, M., and Bouya, B. 2002. A new large mammal from the Ypresian of Morocco: evidence of surprising diversity of early proboscideans. Acta Palaeontologica Polonica, 47:493-506.

Gheerbrant, E., Sudre, J., Cappetta, H., Mourer-Chauviré, C., Bourdon, E., larochene, M., Amaghzaz, M., and Bouya, B. 2003. Les localités à mammifères des carrières de Grand Daoui, bassin des Ouled Abdoun, Maroc, Yprésien : premier état des lieux. Bulletin de la Société Géologique de France, 174:271-278.

Gingerich, P.D. 1993. Oligocene age of the Gebel Qatrani Formation, Fayum, Egypt. Journal of Human Evolution , 24:207-218

Gingerich, P.D. and Deutsch, H.A. 1989. Systematics and evolution of early Eocene Hyaenodontidae (Mammalia, Creodonta) in the Clarks Fork Basin, Wyoming. Contributions from the Museum of Paleontology, The University of Michigan, 27:327-391.
Grohé, C., Morlo, M., Chaimanee, Y., Blondel, C., Coster, P., Valentin, X., Salem, M., Bilal, A.A., Jaeger, J.-J., and Brunet, M. 2012. New Apterodontinae (Hyaenodontida) from the Eocene Locality of Dur atTalah (Libya): Systematic, Paleoecological and Phylogenetical Implications. PloS ONE 7, e49054. doi:10.1371/journal.pone.0049054

Hartenberger, J.-L. 1986. Hypothese paleontologique sur l'origine des Macroscelidae (Mammalia). Comptes Rendus de l'Académie des Sciences, Série 2, 302:247-249.

Hartenberger, J. L., Crochet, J.-Y., Martinez, C., Feist, M., Godinot, M., Mannai Tayech, B., Marandat, B., and Sigé, B. 1997. Le gisement de mammifères de Chambi (Eocène, Tunisie centrale) dans son contexte géologique. Apport à la connaissance de l'évolution des mammifères en Afrique, p. 263-274. In Aguilar, J.-P., Legendre, S., and Michaux J. (eds.), Actes $d u$ Congrès BiochroM'97, Montpellier. Mémoires des Travaux de l'E.P.H.E.

Hartenberger, J.-L., Crochet, J.-Y., Martinez, C., Marandat, B., and Sigé, B. 2001. The Eocene mammalian fauna of Chambi (Tunisia) in its geological context, $p$. 237-250. In Gunnell G.F. (ed.), Eocene Biodiversity: Unusual Occurrences and Rarely Sampled Habitats). Kluwer Academic/Plenum, New York

Hartenberger, J.-L. and Marandat, B. 1992. A new genus and species of an early Eocene primate from North Africa. Human Evolution, 7:9-16.

Hartenberger, J.-L., Martinez, C., and Ahmed, B.S. 1985. Découverte de mammifères d'âge Eocène inférieur en Tunisie centrale. Comptes Rendus de l'Académie des Sciences, Série 2, 301:649-652.

Holroyd, P.A. 1994. An examination of dispersal origins for Fayum Mammalia. Unpublished PhD Thesis, Duke University, Durham, North Carolina, USA.

Holroyd, P.A. 1999. New Pterodontinae (Creodonta: Hyaenodontidae) from the late Eocene-early Oligocene Jebel Qatrani Formation, Fayum province, Egypt. PaleoBios, 19:1-18.

Holroyd, P.A., Lihoreau, F., Gunnell, G. F., and Miller, E. 2010. Anthracotheriidae, p. 843-852. In Werdelin, L. and Sanders W.J. (eds.), Cenozoic Mammals of Africa. University of California Press, Berkeley.

Holroyd, P.A., Simons, E.L., Bown, T.M., Polly, P.D., and Kraus, M.J., 1996. New records of terrestrial mammals from the upper Eocene Qasr el Sagha Formation, Fayum Depression, Egypt. Palaeovertebrata, 25:175-192.

Hren, M.T., Sheldon, N.D., Grimes, S.T., Collinson, M.E., Hooker, J.J., Bugler, M., and Lohmann, K.C. 2013. Terrestrial cooling in Northern Europe during the Eocene-Oligocene transition. Proceedings of the National Academy of Sciences, 110:7561-7567.

Jacobs, B.F., Pan, A.D., and Scotese, C.R. 2010. A review of the Cenozoic vegetation history of Africa, $p$. 57-72. In Werdelin, L. and Sanders W.J. (eds.), Cenozoic Mammals of Africa. University of California Press, Berkeley. 
Jaeger, J.-J., Beard, K.C., Chaimanee, Y., Salem, M., Benammi, M., Hlal, O., Coster, P., Bilal, A.A., Duringer, P., Schuster, M., Valentin, X., Marandat, B., Marivaux, L., Métais, E., Hammuda, O., and Brunet, M. 2010. Late middle Eocene epoch of Libya yields earliest known radiation of African anthropoids. Nature, 467:1095-1098.

Jaeger, J.-J., Denys, C., and Coiffait, B. 1985. New Phiomorpha and Anomaluridae from the late Eocene of North-West Africa: phylogenetic implications, p. 567588. In Luckett, W.P. and Hartenberger, J.-L. (eds.), Evolutionary Relationships among Rodents, A Multidisciplinary Analysis. Nato, New York and London.

Lange-Badré, B. 1979. Les Créodontes (Mammalia) d'Europe occidentale de l'Eocène supérieur à l'Oligocène supérieur. Mémoires du Muséum National d'Histoire Naturelle, 42:1-249.

Lange-Badré, B. and Böhme, M., 2005. Apterodon intermedius, sp. nov., a new European creodont mammal from MP22 of Espenhain (Germany). Annales de Paléontologie, 91:311-328.

Leidy, J. 1869. On the extinct Mammalia of Dakota and Nebraska: including an account of some allied forms from other localities, together with a synopsis of the mammalian remains of North America. Journal of the Academy of Natural Sciences Philadelphia, 7:1-472.

Lewis, M.E. and Morlo, M. 2010. Creodonta, p. 543-560. In Werdelin, L. and Sanders W.J. (eds.), Cenozoic Mammals of Africa. University of California Press, Berkeley.

Lihoreau, F., Boisserie, J.-R., Manthi, F.K., and Ducrocq, S. 2015. Hippos stem from the longest sequence of terrestrial cetartiodactyl evolution in Africa. Nature communications, 6:6264. doi:10.1038/ncomms7264

Linnaeus, C. 1758. Systema Naturae per regna tria naturae, secundum classes, ordines, genera, species, cum characteribus, differentiis, synonymis, locis. Editio decima, reformata. Holmiae: Laurentius Salvius.

Liu, A.G., Seiffert, E.R., and Simons, E.L. 2008. Stable isotope evidence for an amphibious phase in early proboscidean evolution. Proceedings of the National Academy of Sciences, 105:5786-5791.

Mahboubi, M., Ameur, R., Crochet, J.Y., and Jaeger, J.J. 1986. El Kohol (Saharan atlas, Algeria): a new Eocene mammal locality in northwestern Africa. Palaeontographica A, 192:15-49.

Marivaux, L., Adaci, M., Bensalah, M., Rodrigues, H.G., Hautier, L., Mahboubi, M., Mebrouk, F., Tabuce, R., and Vianey-Liaud, M. 2011. Zegdoumyidae (Rodentia, Mammalia), stem anomaluroid rodents from the early to middle Eocene of Algeria (Gour Lazib, Western Sahara): new dental evidence. Journal of Systematic Palaeontology, 9:563-588.

Marivaux, L., Essid, E.M., Marzougui, W., Khayati Ammar, H., Adnet, S., Marandat, B., Merzeraud, G., Ramdarshan, A., Tabuce, R., Vianey-Liaud, M., and Yans, J. 2014b. A morphological intermediate between eosimiiform and simiiform primates from the late middle Eocene of Tunisia: Macroevolutionary and paleobiogeographic implications of early anthropoids. American journal of physical anthropology, 154:387-401.

Marivaux, L., Essid, E.M., Marzougui, W., Khayati Ammar, H., Adnet, S., Marandat, B., Merzeraud, G., Tabuce, R., and Vianey-Liaud, M. 2014a. A new and primitive species of Protophiomys (Rodentia, Hystricognathi) from the late middle Eocene of Djebel El Kébar, Central Tunisia. Palaeovertebrata, 38:1-17.

Marivaux, L., Essid, E. M., Marzougui, W., Khayati Ammar, H., Merzeraud, G., Tabuce, R., and VianeyLiaud, M. 2015. The early evolutionary history of anomaluroid rodents in Africa: new dental remains of a zegdoumyid (Zegdoumyidae, Anomaluroidea) from the Eocene of Tunisia. Zoologica Scripta, 44:117134.

Marivaux, L., Ramdarshan, A., Essid, E.M., Marzougui, W., Ammar, H.K., Lebrun, R., Marandat, B., Merzeraud, G., Tabuce, R., and Vianey-Liaud, M. 2013. Djebelemur, a tiny pre-tooth-combed primate from the Eocene of Tunisia: a glimpse into the origin of crown strepsirhines. PloS ONE, 8:e80778. doi: 10.1371/journal.pone.0080778

Martin, R. 1906. Revision der obereocaenen und unteroligocaenen Creodonten Europas, Revue Suisse de Zoologie, 14:405-600.

Meng, J., Zhai, R.-J., and Wyss, A.R. 1998. The late Paleocene Bayan Ulan fauna of Inner Mongolia, China. Bulletin of Carnegie Museum of Natural History, 34:148-185.

Miller, K.G., Browning, J.V., Aubry, M.-P., Wade, B.S., Katz, M.E., Kulpecz, A.A., and Wright, J.D. 2008. Eocene-Oligocene global climate and sea-level changes: St. Stephens Quarry, Alabama. Geological Society of America Bulletin, 120:34-53.

Morlo, M. and Gunnell, G.F. 2005: New species of Limnocyon (Mammalia, Creodonta) from the Bridgerian (Middle Eocene). Journal of Vertebrate Paleontology, 25:251-255.

Morlo, M., Gunnell, G.F., and Polly, P.D. 2009. What, if not nothing, is a creodont? Phylogeny and classification of Hyaenodontida and other former creodonts. Journal of Vertebrate Paleontology Program and Abstracts, 2009:152A.

Morlo, M., Gunnell, G.F., and Nagel, D., 2010. Chapter 10 - Ecomorphological analysis of carnivore guilds in the Eocene through Miocene of Laurasia, p. 269-310. In Goswami, A. and Friscia, A. (eds.), New contributions to the Natural History of Carnivora. Cambridge University Press, Cambridge, U.K.

Osborn, H. 1909. New carnivorous mammals from the Fayum Oligocene, Egypt. Bulletin of the American Museum of Natural History, 26:415-424.

Partridge, T.C. 2010. Tectonics and Geomorphology of Africa during the Phanerozoic, p. 3-18. In Werdelin, L. and Sanders W.J. (eds.), Cenozoic Mammals of Africa. University of California Press, Berkeley.

Peigné, S., Morlo, M., Chaimanee, Y., Ducrocq, S., Tun, S.T., and Jaeger, J.-J. 2007. New discoveries of 
hyaenodontids (Creodonta, Mammalia) from the Pondaung Formation, middle Eocene, Myanmar -paleobiogeographic implications. Geodiversitas, 29:441-458.

Pickford, M., Senut, B., Morales, J., Mein, P., and Sanchez, I.M. 2008. Mammalia from the Lutetian of Namibia. Memoirs of the Geological Survey of Namibia, 20:465-514.

Pilgrim, G.E. 1932. The fossil carnivora of India. The fossil Carnivora of India. Memoirs of the Geological Survey of India, Palaeontologia Indica, 18:1-232.

Polly, P.D. 1996. The skeleton of Gazinocyon vulpeculus gen. et comb.nov. and the cladistic relationships of Hyaenodontidae (Eutheria,Mammalia). Journal of Vertebrate Paleontology, 16:303-319.

Rana, R., Kumar, K., Zack, S., Solé, F., Rose, K.D., Missiaen, P., Singh, L., Sahni, A., and Smith, T. 2015. Craniodental and postcranial morphology of Indohyaenodon raoi from the early Eocene of India, and its implications for ecology, phylogeny, and biogeography of hyaenodontid mammals. Journal of Vertebrate Paleontology, 35 (e965308):1-22.

Rasmussen, D.T. and Gutierrez, M. 2009. A mammalian fauna from the Late Oligocene of northwestern Kenya. Palaeontographica A, 288:1-52.

Ravel, A., Adaci, M., Bensalah, M., Charruault, A.-L., Essid, E. M., Khayati Ammar, H., Mahboubi, M., Marzougui, W., Mebrouk, F., Merzeraud, G., VianeyLiaud, M., Tabuce, R., and Marivaux, L. In press. Origine et radiation initiale des chauves-souris modernes: nouvelles découvertes dans l'Éocène d'Afrique du Nord (Origin and radiation of modern bats: new discoveries in the Eocene of North Africa). Geodiversitas.

Ravel, A., Adaci, M., Bensalah, M., Mahboubi, M., Mebrouk, F., Essid, E. M., Marzougui, W., Khayati Ammar, H., Charruault, A.-L., Lebrun, R., Tabuce, R., Vianey-Liaud, M., and Marivaux, L. 2015. New philisids (Mammalia, Chiroptera) from the Early-Middle Eocene of Algeria and Tunisia: new insight into the phylogeny, paleobiogeography and paleoecology of the Philisidae. Journal of Systematic Palaeontology, 13:691-709.

Ravel, A., Marivaux, L., Tabuce, R., Adaci, M., Mahboubi, M., Mebrouk, F., and Bensalah, M. 2011b. The oldest African bat from the early Eocene of El Kohol (Algeria). Naturwissenschaften, 98:397-405.

Ravel, A., Marivaux, L., Tabuce, R., Adaci, M., Mahboubi, M., Mebrouk, F., Bensalah, M., Ali, B.H., Essid, E.M., and Vianey-Liaud, M. 2011a. Eocene Chiroptera from Tunisia and Algeria: new insight into the early evolution of bats in North Africa, p. 139-140. In Lehmann, T. and Schaal, S.F.K. (eds.), The World at the Time of Messel: Puzzles in Palaeobiology, Palaeoenvironment and the History of Early Primates, 22nd International Senckenberg. Senckenberg Gesellschaft für Naturforschung, Frankfurt.

Ravel, A., Marivaux, L., Tabuce, R., Ben Haj Ali, M., Essid, E., and Vianey-Liaud, M. 2012. A new large philisid (Mammalia, Chiroptera, Vespertilionoidea) from the late Early Eocene of Chambi, Tunisia. Palaeontology, 55:1035-1041.

Sallam, H.M. and Seiffert, E.R. 2016. New phiomorph rodents from the latest Eocene of Egypt, and the impact of Bayesian "clock"-based phylogenetic methods on estimates of basal hystricognath relationships and biochronology. PeerJ, 4 (e1717):1-53.

Sallam, H.M., Seiffert, E.R., and Simons, E. 2011. Craniodental morphology and systematics of a new family of hystricognathous rodents (Gaudeamuridae) from the Late Eocene and Early Oligocene of Egypt. PloS ONE, 6:1-29. doi: 10.1371/journal.pone.0016525

Sallam, H.M., Seiffert, E.R., and Simons, E.L. 2012. A basal phiomorph (Rodentia, Hystricognathi) from the late Eocene of the Fayum Depression, Egypt. Swiss Journal of Palaeontology, 131:283-301.

Sallam, H.M., Seiffert, E.R., Steiper, M.E., and Simons E.L. 2009. Fossil and molecular evidence constrain scenarios for the early evolutionary and biogeographic history of hystricognathous rodents. Proceedings of the National Academy of Sciences, 106:16722-16727.

Sanders, W.J., Gheerbrant, E., Harris, J.M., Saegusa, H., and Delmer, C. 2010. Proboscidea, p. 161-252. In Werdelin, L. and Sanders W.J. (eds.), Cenozoic Mammals of Africa. University of California Press, Berkeley.

Sanders, W. and Seiffert, E. 2014. Proboscideans from the late Eocene Birket Qarun Formation of northern Egypt, and their biochronological implications. Journal of Vertebrate Paleontology Program and Abstracts, 2014:220-221.

Savage, R.J. 1965. The Miocene Carnivora of East Africa. Bulletin of the British Museum of Natural History Geology, 10:239-316.

Seiffert, E.R. 2006. Revised age estimates for the later Paleogene mammal faunas of Egypt and Oman. Proceedings of the National Academy of Sciences, 103:5000-5005.

Seiffert, E.R. 2007a. A new estimate of afrotherian phylogeny based on simultaneous analysis of genomic, morphological, and fossil evidence. BMC Evolutionary Biology 7:1-13

Seiffert, E.R., 2007b. Evolution and extinction of AfroArabian primates near the Eocene-Oligocene boundary. Folia Primatologica, 78:314-327.

Seiffert, E.R. 2010. Chronology of Paleogene mammal localities, p. 19-26. In Werdelin, L. and Sanders W.J. (eds.), Cenozoic Mammals of Africa. University of California Press, Berkeley.

Seiffert, E.R., Bown, T.M., Clyde, W.C., and Simons, E. 2008. Geology, paleoenvironment, and age of Birket Qarun Locality 2 (BQ-2), Fayum Depression, Egypt, p. 71-86. In Fleagle, J.G, Gilbert, C.C. (eds.), Elwyn Simons: A Search for Origins. Springer, New York.

Simons, E.L. and Gingerich, P.D. 1974. New carnivorous mammals from the Oligocene of Egypt. Annals of the Geological Survey of Egypt, 4:157-166. 
Simons, E.L. and Gingerich, P.D. 1976. A new species of Apterodon (Mammalian Creodonta) from the upper Eocene Qasr el- Sagha Formation of Egypt. Postilla, 168:1-9.

Solé, F. 2013. New proviverrine genus from the Early Eocene of Europe and the first phylogeny of Late Palaeocene-Middle Eocene hyaenodontidans (Mammalia). Journal of Systematic Palaeontology, 11:375398.

Solé, F., Falconnet, J., and Yves, L. 2014a. New proviverrines (Hyaenodontida) from the early Eocene of Europe; phylogeny and ecological evolution of the Proviverrinae. Zoological Journal of the Linnean Society, 171:878-917.

Solé, F., Gheerbrant, E., Amaghzaz, M., and Bouya, B. 2009. Further evidence of the African antiquity of hyaenodontid ("Creodonta", Mammalia) evolution. Zoological Journal of the Linnean Society, 156:827846.

Solé, F., Lhuillier, J., Adaci, M., Bensalah, M., Mahboubi, M., and Tabuce, R. 2014b. The hyaenodontidans from the Gour Lazib area (? Early Eocene, Algeria): implications concerning the systematics and the origin of the Hyainailourinae and Teratodontinae. Journal of Systematic Palaeontology, 12:303-322.

Solé, F., Smith, T., Tabuce, R., and Marandat, B. 2015. New dental elements of the oldest proviverrine mammal, Parvagula palulae, from the Early Eocene of Southern France support possible African origin of the subfamily. Acta Palaeontologica Polonica, 60(3):527-538.

Tabuce, R. 2002. Mammifères du Paléogène ancien d'Afrique du nord occidental : systématique, paléobiogéographie et apport à la phylogénie des "ordres endémiques africains". Unpublished PhD Thesis, Université Montpellier II-Institut des Sciences de I'Evolution, Montpellier, France.

Tabuce, R., Charruault, A.-L., Adaci, M., Bensalah, M., Ben Haj Ali, M., Essid, E.M., Marivaux, L., VianeyLiaud, M., and Mahboubi, M. 2011. The early Eocene radiation of Hyracoidea (Mammalia, Afrotheria): new fieldwork evidence from northwestern Africa, p. 161162. In Lehmann, T. and Schaal, S.F.K. (eds.), The World at the Time of Messel: Puzzles in Palaeobiology, Palaeoenvironment and the History of Early Primates, 22nd International Senckenberg. Senckenberg Gesellschaft für Naturforschung, Frankfurt.

Tabuce, R., Coiffait, B., Coiffait, P.-E., Mahboubi, M., and Jaeger, J.-J. 2000. A new species of Bunohyrax (Hyracoidea, Mammalia) from the Eocene of Bir El Ater (Algeria). Comptes Rendus de l'Académie des Sciences, série 2, 331:61-66.

Tabuce, R., Coiffait, B., Coiffait, P.-E., Mahboudi, M., and Jaeger, J.-J. 2001a. A new genus of Macroscelidae (Mammalia) from the Eocene of Algeria: a possible origin of elephant shrews. Journal of Vertebrate Paleontology, 21:535-546.
Tabuce, R., Coiffait, B., Coiffait, P.E., Mahboubi, M., and Jaeger, J.J. 2001b. Knowledge of the evolution of African Paleogene mammals: contribution of the Bir El Ater locality (Eocene, Algeria), p. 215-229. In Denys, C., Granjon, L., and Poulet, A. (eds.), African Small Mammals. IRD Editions, Paris, France.

Tabuce, R., Marivaux, L., Adaci, M., Bensalah, M., Hartenberger, J.-L., Mahboubi, M., Mebrouk, F., Tafforeau, P., and Jaeger, J.-J. 2007. Early Tertiary mammals from North Africa reinforce the molecular Afrotheria clade. Proceedings of the Royal Society B: Biological Sciences, 274:1159-1166.

Tabuce, R., Marivaux, L., Lebrun, R., Adaci, M., Bensalah, M., Fabre, P.-H., Fara, E., Rodrigues, H.G., Hautier, L., Jaeger, J.-J., Lazzari, V., Mebrouk, F., Peigné, S., Sudre, J., Tafforeau, P., Valentin, X., and Mahboubi, M. 2009. Anthropoid versus strepsirhine status of the African Eocene primates Algeripithecus and Azibius: craniodental evidence. Proceedings of the Royal Society B: Biological Sciences, 276:40874094.

Tong, Y. and Wang, J. 2006. Fossil mammals from the Early Eocene Wutu Formation of Shandong Province. Palaeontologia Sinica, new series C, 192:1195.

Van Valen, L. 1966. Deltatheridia, a new order of mammals. Bulletin of the American Museum of Natural History, 132:1-126.

Van Valen, L. 1967. New Paleocene insectivores and insectivore classification. Bulletin of the American Museum of Natural History, 135:217-284.

Vialle, N., Merzeraud, G., Delmer, C., Feist, M., Jiquel, S., Marivaux, L., Ramdarshan, A., Vianey-Liaud, M., Essid, E.M., Marzougui, W., Ammar, H.K., and Tabuce, R. 2013. Discovery of an embrithopod mammal (Arsinoitherium?) in the late Eocene of Tunisia. Journal of African Earth Sciences, 87:86-92.

Vianey-Liaud, M., Jaeger, J.J., Hartenberger, J.L., and Mahboubi, M. 1994. Les rongeurs de l'Eocène d'Afrique nord-occidentale [Glib Zegdou (Algérie) et Chambi (Tunisie)] et l'origine des Anomaluridae. Palaeovertebrata, 23:93-118.

Woodburne, M.O., Gunnell, G.F., and Stucky, R.K., 2009. Climate directly influences Eocene mammal faunal dynamics in North America. Proceedings of the National Academy of Sciences, 106:13399-13403.

Yans, J., Amaghzaz, M., Bouya, B., Cappetta, H., lacumin, P., Kocsis, L., Mouflih, M., Selloum, O., Sen, S., Storme, J.-Y., and Gheerbrant, E. 2014. First carbon isotope chemostratigraphy of the Ouled Abdoun phosphate Basin, Morocco; implications for dating and evolution of earliest African placental mammals. Gondwana Research, 25:257-269.

Zachos, J.C., Breza, J.R., and Wise, S.W., 1992. Early Oligocene ice-sheet expansion on Antarctica: Stable isotope and sedimentological evidence from Kerguelen Plateau, southern Indian Ocean. Geology, 20:569-573. 
Zachos, J.C., Dickens, G.R., and Zeebe, R.E. 2008. An early Cenozoic perspective on greenhouse warming and carbon-cycle dynamics. Nature, 451:279-283.

Zachos, J., Pagani, M., Sloan, L., Thomas, E., and Billups, K. 2001. Trends, rhythms, and aberrations in global climate $65 \mathrm{Ma}$ to present. Science, 292:686693.

Zack, S.P. 2013. A reassessment of the monophyly of Carnivoramorpha (Mammalia). Journal of Vertebrate Paleontology, Program and Abstracts, 2013:242. 